\title{
Merkel Cell Polyomavirus: A Causal Factor in Merkel Cell Carcinoma
}

\author{
Marijke Van Ghelue ${ }^{1}$ and Ugo Moens ${ }^{2}$ \\ ${ }^{1}$ Department of Medical Genetics, \\ University Hospital Northern-Norway, Tromsø, Norway \\ 2University of Tromsø, Faculty of Health Sciences, \\ Department of Medical Biology, Tromsø, \\ Norway
}

\section{Introduction}

The RNA viruses hepatitis C virus and human T-cell lymphotropic virus type I (or human T-cell leukaemia virus type 1), and the DNA viruses hepatitis B virus, high-risk human papillomaviruses, human herpes virus-8 (Kaposi's sarcoma-associated herpes virus) and Epstein Barr virus are acknowledged as carcinogenic to humans. Human polyomaviruses have oncogenic potentials in cell cultures and animal models, but their role in human cancer remains controversial. In 2008, a new polyomavirus member discovered in Merkel cell carcinoma tissue was concordantly named Merkel cell polyomavirus (MCPyV). Subsequent epidemiologic studies have shown that viral DNA is present in approximately $80 \%$ of Merkel cell carcinomas investigated and MCPyV positive Merkel cell carcinoma have a higher virus load than non-malignant tissues. In addition, the patients have higher viral antibody levels than controls. Moreover, the viral genome seems monoclonally integrated in the primary tumour and in metastatic cells, and expresses a truncated version of the major oncoprotein, large $\mathrm{T}$-antigen. This C-terminal truncated large $\mathrm{T}$-antigen retains its DnaJ and retinoblastoma binding domains, which are necessary for transformation of cells in vitro, but lacks its DNA helicase activity so that it cannot sustain viral DNA replication. These observations suggest that $\mathrm{MCPyV}$ can contribute to Merkel cell carcinoma pathogenesis and may therefore add a new virus to the list of human cancer viruses. Here we present information on the biology of polyomaviruses with special focus on $\mathrm{MCPyV}$, review the role of MCPyV in Merkel cell carcinoma, and discuss the molecular mechanisms by which this virus may induce cancer.

\section{Merkel cell carcinoma}

Merkel cells, originally described by Friedrich Sigmund Merkel in 1875, are believed to migrate during development from the neural crest to the basal layer of the epidermal cells near the end of axons and the outer root sheet of hair follicles [Szeder et al., 2003; Calder \& Smoller, 2010]. These cells are especially dense in the skin of the limbs and face, and around hair follicles, but they are also present in oral mucus membranes [Lacour et al., 1991]. Their 
role remains incompletely understood, but they may function as mechanoreceptors or chemoreceptors [Mahrle \& Orfanos, 1974]. This was recently supported by phenotypic observations in conditional knock out mice deficient in expressing the transcription factor Atoh1 [Van Keymeulen et al., 2009]. These mice lacked Merkel cells and ex vivo skin/nerve preparations of these animals demonstrated complete loss of the characteristic neurophysiologic responses normally mediated by Merkel cell-neurite complexes. Merkel cells are therefore required for the proper encoding of Merkel receptor responses, suggesting that these cells form an indispensible part of the somatosensory system [Maricich et al., 2009]. Although data suggest that Merkel cells may have a neural crest origin [reviewed in Moll et al., 2005; Boulais \& Misery, 2007, The Rockville MCC group, 2009], they also express the epithelial marker cytokeratin 20 (CK20) [Southgate et al., 1999], indicating an epithelial origin. In 1972, Toker described an unusual form of skin cancer as trabecular carcinoma of the skin [Toker, 1972]. Later, these carcinomas were shown to derive from Merkel cells and this type of cancer was therefore renamed Merkel cell carcinoma (MCC) [Gould et al., 1985]. Whether MCC arises from normal Merkel cells is still controversial [The Rockville MCC group, 2009]. Currently, MCC is thought to originate from a primitive totipotent stem cell with the ability to differentiate along divergent histological phenotypes [Calder \& Smoller, 2010].

MCC is a rare but aggressive skin cancer of neuroendocrine origin with propensity for local recurrence and regional lymph node metastasis. MCC is most common on the head and neck (approximately $50 \%$ of the cases) and the extremities ( $40 \%$ of the patients), and the remaining cases occur on the trunk and on genitalia [Pectasides et al., 2006; Lemos \& Nghiem, 2007; Heymann, 2008; Becker et al., 2009; Pulitzer et al., 2009]. MCC is heterogeneous clinically, morphologically and in expression of neuroendocrine, epithelial and oncogenic markers. Histological characterization of the MCC is based on demonstration of cytoplasmic neurosecretory granules of Merkel cell by electron microscopy and positive immunohistochemical staining for cytokeratins CK20, Cam 5.2, CD56, and neuroendocrine markers such as chromogranin A, synaptophysin and neuron-specific enolase [Heymann, 2008]. Classic MCC cell lines grow as non-adherent, clustered cells, while variant MCC cells grow as adherent cells [Leonard et al., 1995]. Comparing the gene expression profile between these two distinct MCC subtypes revealed higher transcript levels of genes encoding signal transduction proteins in classic MCC, while variant MCC possessed elevated transcription of cell cycle genes [Van Gele et al., 2004].

MCC is extremely unusual before the age of $50(\sim 5 \%$ of the cases) and people at risk include those with fair skin, excessive UV-light exposure and immunosuppressed patients. The median age at presentation is 76 years for women and 74 years for men and there is a slight male predominance [Calder \& Smoller, 2010]. The majority of the patients are white $(94.9 \%)$ and chronically immunosuppressed individuals are 10 to 15 times more likely to develop MCC than age-matched controls. Moreover, this malignancy is more lethal in immunodeficient patients than in immunocompetent individuals [Engels et al., 2008; Houben et al., 2009; Becker et al., 2009; Pulitzer et al., 2009; The Rockville MCC group, 2009; Wong \& Wang, 2010; Calder \& Smoller, 2010]. The incidence rate is 0.44 cases per 100,000 individuals in the USA and 0.15 cases per 100,000 individuals in Japan. The number of MCC cases has tripled the last 15 years [Hodgson, 2005; Nakajima et al., 2009]. The reason for this may be ageing of the population and improved diagnosis. So far, no optimal therapeutic regime exists so that surgical excision of the primary tumour and 
lymph node dissection, followed by postoperational radiation therapy is the standard practice. Although MCC is claimed to be an aggressive cancer, a retrospective study on almost 4,000 patients has shown that the 10 -year relative survival rate is $57 \%$ [AlboresSaavedra et al., 2009].

The molecular mechanisms that drive the pathogenesis of MCC remain incompletely understood. Aberrant DNA methylation of the promoters of the cyclin-dependent protein kinase inhibitor p14 $\mathrm{ARF}$ and the tumour suppressor RASSF1A is believed to be important in MCC tumorigenesis [Lassacher et al., 2008]. Heterozygous loss of chromosome 10q23, which contains the tumour suppressor PTEN, overexpression of the anti-apoptotic proteins Bcl-2 and survivin, and of the L-myc proto-oncogene have frequently been observed in MCC, while expression levels of the p53 family member p63 correlates with the aggressiveness of the cancer [Kennedy et al., 1996; Feinmesser et al., 1999; Van Gele et al., 2001; Asioli et al., 2007; Kim \& McNiff, 2008; Paulson et al., 2009]. However, the role of these events in MCC has to be established. The recent discovery of the presence of a new polyomavirus in most MCC may have shed some light on the enigma what may be a major cause of MCC.

\section{Human polyomaviruses}

Members of the Polyomaviridae family are characterized by a double-stranded circular DNA genome surrounded by a viral protein structure, referred to as capsid. They lack, however, a host-cell derived lipid structure known as the envelope. The virus particles are about $45 \mathrm{~nm}$ in diameter and the viral genome is approximately 5,000 base-pairs [Imperiale \& Major, 2007]. The first member of this family was isolated in from mice 1953. The name polyomavirus ("poly" for many and "oma" for cancer) refers to the virus' ability to induce different types of tumours when injected in mice [reviewed in Stoner \& Hübner, 2001]. The oncogenic properties of mouse polyomavirus encouraged scientists in their search to isolate other polyomaviruses, including human polyomaviruses. In 1960, the second member of this family was isolated from monkey kidney cells used for producing poliovirus vaccine. This virus was named simian virus 40 (SV40) and could transform cell culture, including human cells and induce tumours in animal models [Vilchez \& Butel, 2004]. In 1971, two independent research groups reported the isolation of the first human polyomaviruses. One virus was detected in the urine of a kidney transplant recipient with the initials B.K., while the other human polyomavirus was isolated from the brain of a Hodgkin lymphoma patient with the initials J.C. who suffered from progressive multifocal leukoencephalopathy (PML). These viruses were named as BK virus (BKV) and JC virus (JCV), respectively [Gardner et al., 1971; Padgett et al., 1971]. The International Committee on Taxonomy of Viruses recommends using the abbreviations BKPyV and JCPyV, respectively [Johne et al., 2011].

SV40 and lymphotropic polyomavirus (LPyV), another monkey virus also seem to infect the human population, but with a much lower incidence than BKPyV and JCPyV. Whereas up to $90 \%$, respectively $60 \%$ of the adults have antibodies against $\mathrm{BKPyV}$, respectively JCPyV. SV40 and LPyV infections are less common with only $2 \%$ of the human population showing specific anti-SV40 antibodies and 15\% possessing anti-LPyV antibodies [Knowles, 2006; Carter et al., 2009; Kean et al., 2009]. The latter number may be overestimated because recently a new human polyomavirus (HPyV9) that is closely related to LPyV has been isolated so that the seropositivity to LPyV may be partially explained by cross-reactivity 
with HPyV9 [Scuda et al., 2011]. Human polyomaviruses establish a life-long latent infection in immunocompetent hosts, while immunocompromised individuals such as autoimmune patients and AIDS patients or immunosuppressive treatment such as in bone marrow and renal transplant patients may lead to reactivation of the viruses. Reactivation of BKPyV can lead to nephropathy or hemorrhagic cystitis, while JCPyV is the causative agent of progressive multifocal leukoencephalopathy [Jiang et al., 2009].

For many years, occurrence of the known human polyomaviruses in individuals was monitored mostly by PCR and serological methods. In recent years, mainly by use of novel methodology, several new polyomaviruses have been isolated. They include KIPyV, WUPyV, HPyV6, HPyV7, trichodysplasia spinulosa-associated polyomavirus (TSPyV), and HPyV9 [Allander et al., 2007; Gaynor et al., 2007; Schowalter et al., 2010; van der Meijden et al., 2010; Scuda et al., 2011; reviewed in Moens et al., 2010 and Moens et al., 2011]. Their role in human pathologies remains unknown, except for TSPyV which may be the etiological factor in trichodysplasia spinulosa, a rare skin disease exclusively found in immunocompromised patients and characterized by the development of follicular papules and keratin spines known as spicules [van der Meijden et al., 2010; Matthews et al., 2011].

Another new polyomavirus was isolated in Merkel cell carcinoma tissue, hence its name Merkel cell polyomavirus or MCPyV [Feng et al., 2008]. Whereas, the role of human polyomaviruses in cancer remains a matter of dispute despite their oncogenic properties in cell culture and in animal models, as well as the presence of viral nucleic acid sequences and proteins in cancer tissue, $\mathrm{MCPyV}$ is considered as an etiological factor in MCC [Abend et al., 2009; Maginnis \& Atwood, 2009; Gjoerup \& Chang, 2010]. This virus and its role in MCC is the focus of this review.

\section{Molecular biology of human polyomaviruses}

The viral genome of human polyomaviruses can be divided into three functional regions: the early region encoding large T-antigen (LT-ag) and small t-antigen (st-ag), the late region encoding the capsid proteins VP1, VP2 and VP3, and the non-coding control region encompassing the origin of replication and promoter sequences that control transcription of the viral genes (Figure 1). LT-ag is required for viral DNA replication and regulates the expression of the viral genes, while st-ag has an auxiliary role for LT-ag. The early region of some human polyomaviruses encodes alternative proteins whose functions are incompletely understood. The late regions of BKPyV, JCPyV and SV40 also contain an ORF for the agnoprotein that is required for efficient virus propagation in cell culture [Carswell \& Alwine, 1986; Khalili et al., 2005; Sariyer et al., 2006; Johannessen et al., 2008; Suzuki et al., 2010]. No corresponding ORF seems to be present in the other human polyomaviruses [Yoshiike \& Takemoto, 1986; Allander et al., 2007; Gaynor et al., 2007; Feng et al., 2008; Schowalter et al., 2010; van der Meijden et al., 2010; Scuda et al., 2011]. The reason why agnoprotein seems to be abundant in the human polyomaviruses LPyV, KIPyV, WUPyV, MCPyV, HPyV6, HPyV7, TSPyV and HPyV, but not in SV40, BKPyV and JCPyV remains mysterious, but it may be because of different life cycle strategies or host cell tropism. SV40 encodes a fifth late protein, referred to as VP4. This protein enhances lysis of the host cell and facilitates release of mature virus particles [Daniels et al., 2007]. KIPyV, WUPyV, MCPyV, TSPyV, HPyV6, HPyV7, and HPyV9 all lack a VP4-like open reading frame $(\mathrm{ORF})$. 


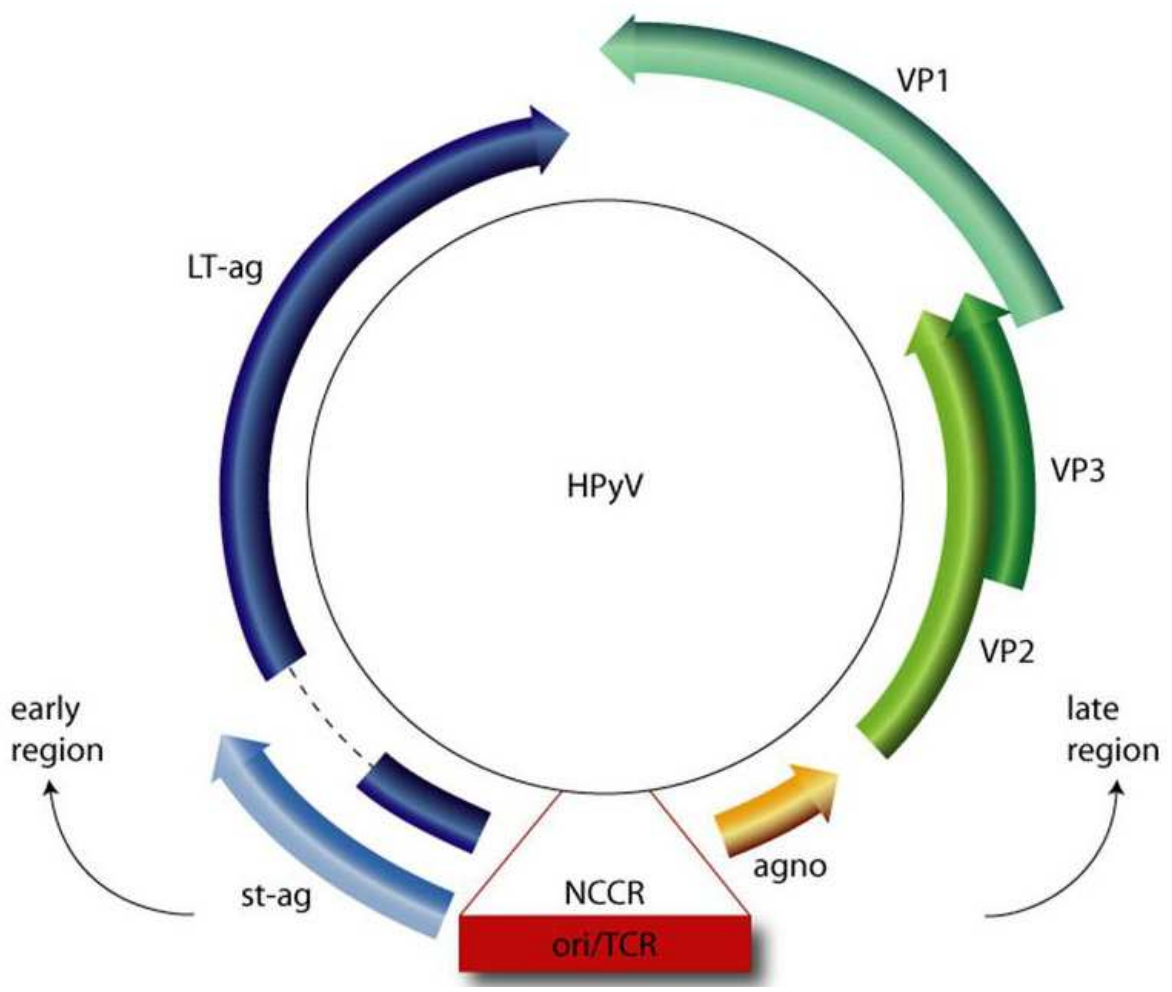

Fig. 1. Genomic organization of human polyomaviruses. The open reading frame encoding agnoprotein (agno) is not present in all human polyomaviruses. See text for details.

BKPyV and JCPyV contain a putative VP4 ORF with the N-terminal MVRQVAxREG amino acid sequence $(x=E$ in $\mathrm{BKPyV}$ and $\mathrm{Q}$ in $\mathrm{JCPyV})$, which is reminiscent of SV40 VP4 (MVRQVANREG), while LPyV has a putative ORF with the N-terminal motif MRQA at the corresponding site. However, VP4 expression by BKPyV, JCPyV and LPyV has not been confirmed.

The genomes of SV40, BKPyV, JCPyV and MCPyV encode a miRNA that down-regulates LT-ag expression levels [Sullivan et al., 2005; Seo et al., 2008]. Cells expressing SV40 miRNA are less susceptible to cytotoxic $T$ cells and trigger less cytokine expression than cells infected with an SV40 mutant lacking miRNA. Hence, miRNA-mediated downregulation of LT-ag levels may allow the virus to escape the immune system [Sullivan et al., 2005]. BKPyV and JCPyV miRNA can also reduce the protein levels of LTag by preventing mRNA translation or targeting it for destruction. Whether this also affects cytotoxic $\mathrm{T}$ cells responses remains unknown. Recent findings by Bauman and colleagues shed light on the molecular mechanism by which these viruses can evade the immune system and remain latent. They demonstrated that JCPyV- and BKPyV-encoded miRNA target the stress-induced ligand ULBP3, which is recognized by the natural killer cell receptor NKG2D. Consequently, viral miRNA downregulation results in reduced 
NKG2D-destruction of BKPyV/JCPyV infected cells by natural killer cells [Bauman et al., 2011]. This miRNA-mediated evasion of the immune system may allow the viruses to establish a latent infection. MCPyV also encodes a miRNA that is antisense to LT-ag mRNA and consequently can reduce the levels of LT-ag [Seo et al., 2009].

\section{Mechanisms by which human polyomaviruses cause cellular transformation}

Infection of cultured cell lines, including human, with SV40, BKPyV, JCPyV and LPyV leads to transformation, while transgenic animals expressing early gene products or animals infected with these viruses can develop tumours [Moens et al., 2007b; Gjoerup and Chang, 2010]. The oncogenic properties of these viruses are primarily attributed to the action of LTag, but also st-ag and agnoprotein possess oncogenic potentials.

LT-ag is a multifunctional protein that is mandatory for viral DNA replication. It contains several functional domains performing different roles (Figure 2). LT-ag binds as an hexamer to $\mathrm{G}(\mathrm{G} / \mathrm{A}) \mathrm{GGC}$ motifs at the viral origin of replication and forms a complex with the cellular replication proteins DNA polymerase $\alpha /$ primase, replication protein $A$, and topoisomerase. LT-ag has also DNA helicase activity that helps unwinding the doublestranded DNA during replication [reviewed in Simmons et al., 2004]. It can bind the tumour suppressors p53 and the retinoblastoma (pRb) family members, thereby forcing the cell into the $S$ phase. This is pivotal for the virus because the virus depends completely on the host cell's DNA replication machinery. LT-ag contains a so-called pRb pocket with the consensus motif LXCXE that is required for interaction with pRb family members. The $\mathrm{pRb}$ family members control $\mathrm{S}$ phase progression by controlling the expression of E2Fresponsive genes. E2F is a family of transcription factors that transcribes genes controlling cell cycle progression and DNA replication such as cyclins, cyclin-dependent kinases, dihydrofolate reductase, thymidine kinase, DNA polymerase I, c-Myc, c-Myb, but also genes whose products are involved in DNA repair, differentiation and apoptosis. Another LT-ag domain that plays a crucial role in regulating the activity of $\mathrm{pRb}$ is the DnaJ domain. This N-terminal located region binds Hsc70, a chaperone with weak intrinsic ATPase activity. The DnaJ domain stimulates Hsc70's ATPase activity and this DnaJ/Hsc70 interaction influences viral DNA replication, transactivation of the viral promoters and viral assembly. Additionally, it is critical for oncogenic transformation via functional inactivation of the $\mathrm{pRb}$ family members. The energy generated by DnaJ domain-mediated hydrolysis of ATP is used to split pRb/E2F complexes [Moens et al., 2007a; Moens et al., 2007b; Gjoerup and Chang, 2010]. The C-terminal domain of LT-ag is involved in binding the tumour suppressor p53. The p53 protein represses cell cycle proliferation and angiogenesis, stimulates apoptosis and is involved in controlling DNA repair [Vogelstein et al., 2000; Vousden et al., 2009]. Several other properties of LT-ag can contribute to neoplastic transformation. It has been shown that LT-ag stimulates telomerase activity, inhibits apoptosis, activates signalling pathways triggering cell cycle progression, interferes with DNA repair and chromosome fidelity, promotes angiogenesis, perturbs protein turn-over, and affects gene expression by interfering with transcription, DNA methylation, chromatine structure. Hence, prolonged LT-ag expression may lead to uncontrolled cell cycle progression, inhibition of angiogenesis and apoptosis, and accumulation of DNA damage [reviewed in Moens et al., 2007a; Moens et al., 2007b; Gjoerup and Chang, 2010]. 


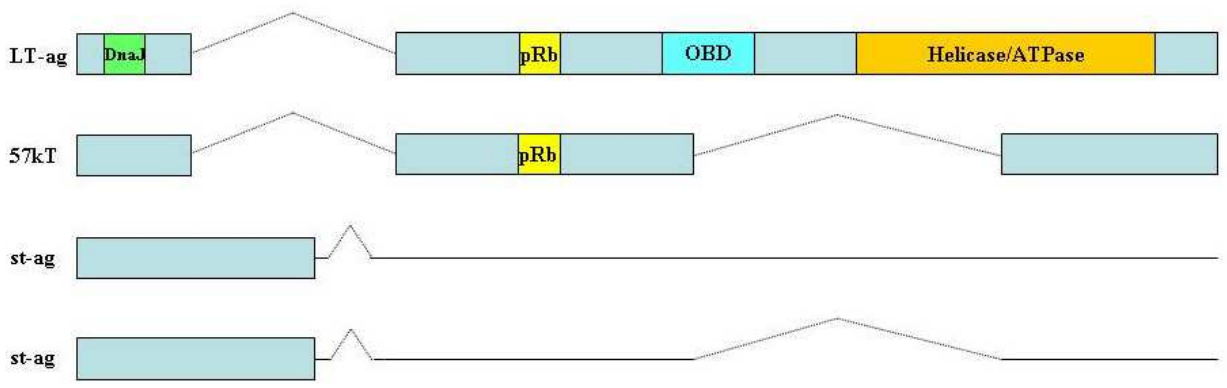

Fig. 2. Functional domains of the human polyomavirus LT-ag and the different splicing products generated from transcription of the early region of $\mathrm{MCPyV}$. These transcripts encode LT-ag, the truncated variant 57kT and two different mRNAs for st-ag. See text for details.

St-ag seems to exert an auxiliary function in LT-ag-mediated transformation. St-ag shares the N-terminal $\sim 80$ amino acids with LT-ag and therefore contains the DnaJ domain, but unlike LT-ag, it lacks the pRb pocket. The major contribution of st-ag in the oncogenic process is through inactivation of protein phosphatase 2A (PP2A). The unique C-terminal part of st-ag binds to the A-subunit of the trimeric PP2A holoenzyme, leading to inhibition of the catalytic activity. St-ag mediated inactivation of PP2A can activate signalling pathways, alter gene expression, inhibit apoptosis/prolongation of cell survival, change protein stability, stimulate telomerase activity, disrupt the cytoskeleton and induce chromosome instability [Moens et al., 2007b].

The agnoprotein of JCPyV can arrest cells in G2/M phase probably through upregulated expression of the cyclin-dependent kinase inhibitor p21 Waf1/Cip1 [Darbinyan et al., 2002]. $\mathrm{JCPyV}$ agnoprotein can interact with the Ku70, which is a component of the nonhomologous end joining (NHEJ) DNA repair complex, leading to inhibition of NHEJ DNA repair [Darbinyan et al., 2004]. Thus, agnoprotein may contribute to transformation through interference with the cell cycle and DNA repair.

Similar studies with the newly discovered human polyomaviruses are lacking, but as these viruses also encode LT-ag and st-ag, it is assumed that they may possess similar oncogenic properties.

\section{Merkel cell polyomavirus (MCPyV): Molecular biology}

In 2008, Feng and colleagues detected two sequences with highest homology to the LT-ags of $\mathrm{LPyV}$ and BKPyV in MCC transcriptomes consisting of $>380,000$ cDNA sequences obtained by pyrosequencing [Feng et al., 2008]. The authors succeeded in cloning and sequencing the entire genome of two variants of this virus, which turned out to be a novel polyomavirus. This new polyomavirus was commonly found in MCC samples and accordingly named Merkel cell polyomavirus (MCPyV). The MCPyV variant 350 (accession number EU375803) and variant 339 (accession number EU375804) diverge by 191 base-pairs inserted in the LT-ag of MCPyV339, 5 base-pairs inserted in the MCPyV 339 non-coding region, and additional 41 nucleotides substitutions dispersed throughout their genomes 
[Feng et al., 2008]. The genetic organization of MCPyV (Figure 3) resembles that of other polyomaviruses, except for the absence of an open reading frame encoding agnoprotein. The early region of $\mathrm{MCPyV}$ encodes three different proteins that are translated from differently spliced transcripts. The LT-ag and st-ag share the N-terminal 79 amino acids, but diverge in their C-terminal domain. The 57kT is identical to LT-ag except for a deletion in the Cterminal region of the protein (Figure 2). The late region encodes the capsid proteins VP1 and VP2, but the VP2 ORF lacks the conserved Met-Ala-Leu motif that forms the start of VP3 in other human polyomaviruses. This may suggest that MCPyV may not encode a functional VP3 [Pastrana et al., 2009]. However, an open reading frame encoding a putative VP3 starting with Met-Thr-Ile is present in both MCC and non-MCC isolates suggesting that a functional VP3 is expressed [Feng et al., 2008; Carter et al., 2009; Schowalter et al., 2010; Touzé et al., 2011]. MCPyV also encodes a viral miRNA that can downregulate the levels of LT-ag [Seo et al., 2009].

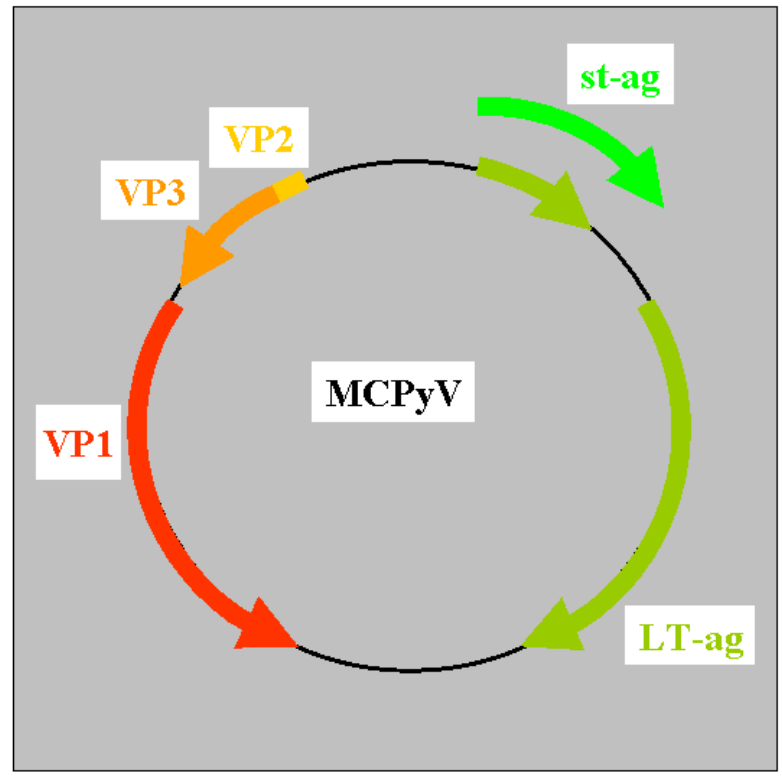

Fig. 3. Genomic organization of MCPyV. The early region encodes for LT-ag, st-ag and 57kT (not shown), while the late region encodes the capsid proteins VP1, VP2 and VP3.

Although originally isolated from MCC, MCPyV infection is probably not restricted to Merkel cells in the skin because these cells make up $<1 \%$ of the cells in the epidermis, yet $\mathrm{MCPyV}$ virions are being shed from the skin at high numbers [Schowalter et al., 2010]. These findings strongly suggest that more common cells in the epidermis like keratinocytes and/or melanocytes may be involved in the production of virions. The presence of $\mathrm{MCPyV}$ in keratinocytes has not been investigated, while MCPyV DNA was not detected in melanocytes [Giraud et al., 2008; Mogha et al., 2010]. Hence, a role for these two cell types as reservoirs for $\mathrm{MCPyV}$ remains unclear. Other cell types in the skin may function as reservoir 
because MCPyV DNA is present in eyebrow hairs, skin lesions and warts from immunocompetent and immunosuppressed patients [Wieland et al., 2009; Schowalter et al., 2010; van der Meijden et al., 2010; Mertz et al., 2010a; Foulongne et al., 2010a].

\section{MCPyV: Route of infection, cell tropism and transmission}

The route of infection of MCPyV is not know, but viral DNA is found in nasal swabs, oral cavity, mouth wash, tonsil biopsies, and oesophagus from healthy individuals, signifying an oral route of infection [Bialasiewicz et al., 2009; Dworkin et al., 2009; Goh et al., 2009; Kantola et al., 2009; Sharp et al., 2009; Loyo et al., 2010; Babakir-Mina et al., 2010]. The primary target cells and the host cells that can function as reservoir are not known, but the virus seems to be common in healthy skin, skin lesions, eyebrow hairs, and warts, indicating a dermatotropism of this virus [Wieland et al., 2009; van der Meijden et al., 2010; Mertz et al., 2010a; Faust et al., 2011; Wieland et al., 2011]. MCPyV DNA is also found in blood, gall bladder, appendix, liver, lung, lymphoid, and intestine tissue [Feng et al., 2008; Sharp et al., 2009; Goh et al., 2009; Shuda et al., 2009; Foulongne et al., 2010a; Husseiny et al., 2010; Loyo et al., 2010; Toracchio et al., 2010; Campello et al., 2011; Pancaldi et al., 2011; reviewed in Moens et al., 2010 and Gjoerup and Chang, 2010]. Another study has suggested that $\mathrm{MCPyV}$ may persist in and spread through inflammatory monocytes [Mertz et al., 2010b].

To expound the cell tropism, Erickson and colleagues identified the MCPyV receptor by using purified VP1 pentamers and liposomes. They found that MCPyV pentamers bound strongly ganglioside GT1b, very weakly GD1b (i.e. the receptor for BKPyV), and not GM1 (i.e. the receptor for SV40) and GD1a (i.e. the mouse polyomavirus receptor). This indicates that GT1b is a putative receptor for $\mathrm{MCPyV}$ and that $\mathrm{MCPyV}$ has different host cell targets than the other HPyV [Erickson et al., 2009]. The binding of MCPyV pentamers to its target receptor may be more complicated. GT1b is abundant in neuronal cell membranes, yet MCPyV DNA seems absent in cerebrospinal fluid and brain and central nervous system tumours [Feng et al., 2008; Barzon et al., 2009; Busam et al., 2009; Giraud et al., 2009]. Moreover, MCPyV pentamers could bind to HeLa (human cervical cancer carcinoma cells) and HEK29T (adenovirus transformed human embryonal kidney cells that express SV40 LTag) cells, which may not be genuine target cells as no MCPyV has been detected in cervical tissue nor in the kidneys so far. Moreover, $\mathrm{MCPyV}$ viruria is rare, indicating that the kidneys may not be an in vivo reservoir [Feng et al., 2008; Giraud et al., 2008; Duncavage et al., 2009a; Katano et al., 2009; Sastre-Garau et al., 2009]. The use of pentamers that may acquire a different conformation than intact virus particles and the requirement of a coreceptor may explain infection of none bona fide host cells.

The way of transmission of MCPyV is also unknown, but the faecal-oral route has been suggested because MCPyV DNA can be detected in samples from the gastrointestinal tract and in urban sewage [Feng et al., 2008; Bofill-Mas et al., 2010; Loyo et al., 2010; Campello et al., 2011]. Moreover, the average viral DNA load in aero-digestive tract is 100 fold higher than the respiratory and genitourinary tract [Loyo et al., 2010]. The results should be interpreted with caution because a limited number of patients were tested. Other studies failed to detect MCPyV DNA in colon adenocarcinoma and in stool samples, jeopardizing a faecal-oral route of transmission [Kantola et al., 2009; Sastre-Garau et al., 2009]. The virus may also spread through respiratory droplets or blood as viral sequences are detected in nasopharyngeal aspirates, nose swabs and blood, but proof for this way of transmission is 
lacking. Moreover, the prevalence of $\mathrm{MCPyV}$ in these samples is lower than in MCC [Dworkin et al., 2009; Helmbold et al., 2009; Kantola et al., 2009; Sharp et al., 2009; Shuda et al., 2009; Tolstov et el., 2009; Mertz et al., 2010b; Babakir-Mina et al., 2010; Loyo et al., 2010; Pancaldi et al., 2011]. Direct contact is most probably the mode of transmission because $\mathrm{MCPyV}$ DNA is frequently detected in benign skin, healthy individuals are chronically infected with $\mathrm{MCPyV}$, and the virus seems to be continuously shed from the skin [Feng et al., 2008; Dworkin et al., 2009; Helmbold et al., 2009; Wieland et al., 2009; Mertz et al., 2010b; Foulongne et al., 2010b; Loyo et al., 2010; Schowalter et al., 2010]. Schowalter and collaborators collected skin swab samples with approximately 3 months interval from 16 volunteers. All samples tested MCPyV DNA positive and contained $\sim 2 \times 10^{6}$ genome equivalents/ml of gradient material. [Schowalter et al., 2010]. Efficient horizontal spreading of $\mathrm{MCPyV}$ through skin-to-skin contact may also explain the high seroprevalence in the human population (see next section). The absence of MCPyV antibodies in children less than 1 year old argues against vertical transmission [Tolstov et al., 2009].

\section{MCPyV seroprevalence}

PCR-based studies have demonstrated that MCPyV infection is common in the normal population and that different tissues can harbour viral DNA [reviewed in Moens et al., 2011]. Serological studies demonstrate that MCPyV infection is widespread in man (Table 1). Of 41 MCC patients (age 42-86 years; 27 men and 14 women) tested, 36 (88\%) had MCPyV VP1 antibodies. Tumour material of 31 MCC patients was available for MCPyV DNA analysis and viral DNA was detected in 24 specimens. Of these 24 patients, 22 (92\%) had MCPyV VP1 antibodies [Carter et al., 2009]. The authors tested 76 age-and sexmatched controls and found that $40(53 \%)$ were seropositive, showing that there was a significant difference $(\mathrm{p}<0.001)$ between the MCC patients and the 76 controls for the presence of $\mathrm{MCPyV}$ antibodies. The same group analyzed another 451 randomly selected women whose age varied between younger than 30 years and $>70$ years and found that $271(60 \%)$ were seropositive. No significant differences were observed with increasing age. The seroprevalences for the age groups <30, 30-39, 40-49, 50-59, 60-69 and $<70$ were $60 \%, 54 \%, 66 \%, 61 \%, 66 \%$ and $58 \%$, respectively. This indicates that most viral infection must have occurred before the age of 30 and that the prevalence was stable at older ages [Carter et al., 2009]. Although this second control group existed exclusively of women, there was no significant difference with the first control group. Thus, the presence of MCPyV VP1 antibodies does not seem to be gender-dependent. Carter and his colleagues found that antibodies in serum samples reacted strongly with VP1 from MCPyV strain w162, while little or no reactivity was found against VP1 from strain 350, although these VP1s differ only by four amino acids [Carter et al., 2009]. Hence, caution must be taken when performing serological studies because the amino acid composition of VP1 in the assay may affect the reactivity of the circulating MCPyV VP1 antibodies in the serum of the patient and therefore the outcome of the test. Kean and co-workers also reported a differential seroreactivity to MCPyV isolates 350 and 339 [Kean et al., 2009]. In their study, 1501 adult healthy blood donors (age $>21$ yrs) were tested and 379 individuals $(25 \%)$ had antibodies that reacted with MCPyV strain 350 recombinant VP1, while 692 blood donors $(46 \%)$ possessed antibodies that recognized strain 339 recombinant VP1. The difference was less in a paediatric cohort <21years of age. Of 721 children examined, $164(23 \%)$ were seropositive for MCPyV strain 350 and 247 (34\%) for strain 339. The authors did not detect 
differences in seroprevalence in respect to gender, nor was there a significant difference in seropositivity between children and adults. This indicates that primary infection occurs during early childhood. However, for $\mathrm{MCPyV}$ strains, there was a tendency to increased seropositivity in elderly individuals.

\begin{tabular}{|c|c|c|c|}
\hline MCPyV positive MCC & Non MCC subjects & $\mathrm{ag}^{\S}$ & reference \\
\hline \multirow[t]{2}{*}{$88 \%(n=41 ;$ age $42-86$ yrs $)$} & $\begin{array}{c}53 \%(\mathrm{n}=76 ; \text { age }<75 \mathrm{yrs}) \\
60 \%(\mathrm{n}=451 ; \text { age } 24-77 \mathrm{yrs})\end{array}$ & VP1 & Carter et al., 1999 \\
\hline & $\begin{array}{l}46 \%(\mathrm{n}=1501 ; \text { age }>21 \mathrm{yrs}) \\
34 \%(\mathrm{n}=721 ; \text { age }<21 \mathrm{yrs})\end{array}$ & VP1 & Kean et al., 1999 \\
\hline $100 \%$ (n=21; age 14-95 yrs) & $88 \%(\mathrm{n}=48 ;$ age $47-75 \mathrm{yrs})$ & VP1 & Pastrana et al., 2009 \\
\hline $100 \%(\mathrm{n}=21 ; \text { age } 14-95 \mathrm{yrs})^{*}$ & $\begin{array}{c}64 \%(n=116 ; \text { age }>18 \text { yrs }) \\
63 \%(n=100 ; \text { age }>47 \text { yrs }) \\
74 \%\left(n=50 ; \text { age } n^{\#}\right)\end{array}$ & VP1 & Tolstov et al., 2009 \\
\hline not tested & $\begin{array}{c}11 \%(\mathrm{n}=217 ; \text { age } 0-13 \text { years }) \\
37 \%(\mathrm{n}=71 ; \text { age } 6-11 \text { years })\end{array}$ & VP1 & Chen et al., 2011 \\
\hline 91\% (n=139; age 31-91 yrs) & $66 \%(n=530 ;$ age-matched) & VP1 & Paulson et al., 2010 \\
\hline $100 \%(\mathrm{n}=51$; age $37-91 \mathrm{yrs})$ & $85 \%(n=82 ;$ age $22-83$ years $)$ & VP1 & Touzé et al..,2011 \\
\hline not tested & $65 \%(\mathrm{n}=434 ;$ age $29-97$ years $)$ & VP1 & Faust et al., 2011 \\
\hline $\begin{array}{l}\text { average VP1 seropositivity: } \\
95 \%(n=252)\end{array}$ & $\begin{array}{c}\text { average VP1 seropositivity: } 57 \% \\
(\mathrm{n}=4397)\end{array}$ & & \\
\hline $26 \%(n=205 ;$ age $31-96$ yrs $)$ & 2\% (n=530; age-matched) & LT-ag & Paulson et al., 2010 \\
\hline $41 \%(n=205 ;$ age $31-96$ yrs $)$ & $1 \%(\mathrm{n}=530 ;$ age-matched $)$ & st-ag & Paulson et al., 2010 \\
\hline
\end{tabular}

santigen; *same patients as in Pastrana et al., 2009; \#nm= not mentioned.

Table 1. Seropositivity against MCPyV VP1, LT-ag and st-ag in MCC and non MCC subjects.

The average seropositivity for strain 350 in individuals $<70$ years is $23 \%$, while $40 \%$ of persons older then 70 had antibodies. Similarly, 38\% of the tested persons younger than 70 were seropositive for $\mathrm{MCPyV}$ strain $339 \mathrm{VP1}$, while $61 \%$ of those older than 70 years were seropositive [Kean et al., 2009]. In another study, the presence of $\mathrm{MCPyV}$ neutralizing antibodies in sera was determined. All $(n=21)$ MCC patients (age 14-95 years) whose tumours were MCPyV DNA positive had specific MCPyV antibodies with a geometric mean titre of 160,000 in the assay used. While 42/48 (88\%) sera of blood donors (age 47-75 years) also contain MCPyV specific antibodies, the mean titre was $\sim 60$ times lower. Similarly, low titres were found in 3 out of $6 \mathrm{MCC}$ patients negative for $\mathrm{MCPyV}$, while the other two patients had no detectable levels of MCPyV antibodies [Pastrana et al., 2009]. This was confirmed by the work of two other groups. Tolstov and collaborators found that IgG levels against the capsid proteins of $\mathrm{MCPyV}$ were higher in $\mathrm{MCPyV}$ positive MCC patients than in $\mathrm{MCPyV}$ negative patients, blood donors and systemic lupus erythematosus (SLE) patients 
[Tolstov et al., 2009]. All of their $21 \mathrm{MCPyV}$ positive MCC patients had significantly higher MCPyV specific IgG antibodies than antibody levels found in 3/6 (50\%) MCPyV negative MCC patients, in 107/166 (64\%) blood donors, in 63/100 (63\%) commercial donors and in $37 / 50(74 \%)$ SLE patients. The IgM levels in all patient groups were comparable [Tolstov et al., 2009]. French MCPyV positive MCC patients had on average 15-fold higher anti-VP1 antibody titres than controls [Touzé et al., 2011]. One obvious explanation for the higher MCPyV-specific antibody titres in MCPyV positive MCC patients is that VP1 is expressed on the cell surface of the tumour cells. However, immunohistochemical staining of $10 \mathrm{MCC}$ tumour cells that had previously shown to express MCPyV LT-ag was negative for VP1, suggesting that VP1 is not expressed in MCC [Pastrana et al., 2009]. Touzé and colleagues were also unable to detect VP1 in 21 MCPyV positive MCC samples obtained from 16 patients [Touzé et al., 2011]. This indicates that tumour cells do not produce VP1 (due to integrational interruption of the late region) or do so at levels undetectable by immunohistochemical staining. Another reason for the higher antibody levels in MCPyV positive MCC patients could be their immunocompromised condition such that a delayed immune response upon primary infection may have resulted in much higher virus load inducing higher titres. Another possibility is that MCPyV may establish a persistent infection in other cell types than Merkel cells in these patients or that unusually high immunogenic MCPyV strains are circulating in these patients [Pastrana et al., 2009]. The fact that a substantial number of individuals of healthy controls and other patient groups displayed MCPyV VP1 antibody titres in the same range as MCPyV positive MCC patients argues against this [Pastrana et al., 2009; Tolstov et al., 2009]. This also implies that not everybody with high MCPyV specific antibody titres develops MCC.

Pastrana and colleagues observed a gradual age-related decline in MCPyV antibody titres for the MCPyV positive MCC patients, but the number in each age category was limited [Pastrana et al., 2009]. This was in contrast with the findings of Tolstov and co-workers in 150 Langerhans cell histiocytosis patients whose age ranged from 1 month to 72 years old. The authors measured an age-dependent increase of MCPyV-specific IgG antibodies with approximately $40 \%$ of the patients younger than 50 years old having antibodies; this number increased to $80 \%$ in patients older than 50 years [Tolstov et al., 2009]. The reason for the opposite results by the two groups remains unknown, but may be due to different assays, different patient groups, or the limited number of individuals examined. Interestingly, none of the six Langerhans cell histiocytosis patients who were less then 1 year old had MCPyV antibodies, arguing against vertical transmission of the virus [Tolstov et al., 2009]. A serological study with 217 Finnish children suffering from acute lower respiratory tract infection confirmed that MCPyV infection probably occurs after the age of one [Chen et al., 2011]. IgG antibodies immunoreactive with VP1 strain 339 were present in sera from 2 out of $51(4 \%)$ children less than 1 year old, while $9 \%(n=140)$ of children between 1 and 4 years of age were seropositive. Seroprevalence increased to $35 \%(n=26)$ in the age category $4-13$ years. The overall seroprevalence was $11 \%$ (24/217). Serum samples obtained 5-8 years later were available for 72 of these 217 children. The initial (at age 0-3 years) MCPyV VP1 IgG positivity rate of $6 \%$ in these children rose to $37 \%(26 / 71)$ during the follow-up. Notably, of the 67 children whose first sample was seronegative, 22 (33\%) were seropositive for their follow-up sample. The same authors also examined 158 children age 1-4 years who had inflammation of the middle ear. Six of them (4\%) were seropositive, while 3 years later, 29 $(18 \%)$ had VP1 antibodies. While in the group of children with acute lower respiratory tract 
infection no significant gender differences were observed, seroprevalence, seroconversion and antibody titres were higher $(\mathrm{p}=0.08, \mathrm{p}=0.08$ and $\mathrm{p}=0.1$, respectively) [Chen et al., 2011]. Another study confirmed the higher prevalence and higher titres of VP1 antibodies in sera from MCC patients compared to control subjects. While $91 \%(n=134)$ of the MCC patients were seropositive, $66 \%(n=530)$ of the controls had anti-VP1 antibodies [Paulson et al., 2010]. The authors included an additional 66 sera from MCC patients and tested for the presence of antibodies against LT-ag and st-ag. While $2 \%$ (respectively $1 \%$ ) control subjects had antibodies against LT-ag (respectively st-ag), 26\% (respectively 41\%) of the MCC patients were seropositive for LT-ag (respectively st-ag). Interestingly, higher MCPyV DNA load in MCC tumours is associated with higher LT-/st-ag antibody titres and patients with advanced disease had significantly higher titres. These results suggest that LT-ag/st-ag antibodies may serve as a clinically useful MCC disease marker [Paulson et al., 2010].

In conclusion, seroprevalence and antibody titres in $\mathrm{MCPyV}$ positive $\mathrm{MCC}$ patients are higher than in control subjects, but $\mathrm{MCPyV}$ infection is very common in the adult population. Results from independent groups revealed that $46-88 \%$ of the non MCC adults (approximately 4,400 subjects) had MCPyV antibodies [Carter et al., 2009; Kean et al., 2009; Pastrana et al., 2009; Tolstov et al., 2009; Paulson et al., 2010; Touzé et al., 2011; Faust et al., 2011]. Serological studies also indicate that primary infection is acquired early in life and that seropositivity inclines with age. MCPyV DNA was amplified in a nasopharyngeal aspirate from a $\sim 2$ month old baby [Bialasiewicz et al., 2009], and the prevalence of MCPyV DNA in these samples increase from $0.6 \%$ in children $<15$ years $(n=340)$ to $8.5 \%$ in adults $\geq 15$ years of age [Goh et al., 2009]. These findings are in agreement with the age-related occurrence of MCPyV antibodies.

\section{MCPyV and MCC: Genoprevalence}

After the original isolation of $\mathrm{MCPyV}$ in MCC, a large number of studies have been performed world-wide to look for viral DNA in MCC. Results from these studies show that approximately $80 \%$ of the examined MCC samples contain MCPyV DNA, hence strongly suggesting $\mathrm{MCPyV}$ as a candidate etiological agent in the development of MCC (Table 2). Although MCC occurs most commonly in the skin, it is also detected in sun-protected sites such as the oral and nasal mucosa, vulva, and penis. In a case report, MCPyV DNA and LTag expression were demonstrated in a patient with nasopharyngeal $\mathrm{MCC}$, both in the primary tumour and in a lymph node metastasis, showing that $\mathrm{MCPyV}$ may also be an etiological factor in these types of MCC [Wu et al., 2010]. MCPyV seems to be distributed globally, but the rates of MCPyV DNA positive MCCs in European (80\%; n=865), North America $(72 \% ; n=254)$ and Asia $(76 \% ; n=58)$ are higher than in Australia $(24 \% ; n=21$; Table 2). However, only a limited number of cases were examined in Asia and in Australian [Garenski et al., 2009; Katano et al., 2009; Nakajima et al., 2009; Woo et al., 2010]. Studies that tested 10 or more subjects, gave a prevalence that varies between $54-88 \%$ for North-America, 64-100\% for Europe, $55-79 \%$ for Asia, and $24 \%$ for Australia.

Recently, an immuno-histochemistry study confirmed that only 19 of 104 (18\%) MCC samples from Australian patients had detectable LT-ag expression [Paik et al., 2011]. It is speculated that owing to increased sun exposure in Australia, viral pathogenesis could be a less important cofactor in MCC. Sun exposure may drive MCC through an alternative, virus-independent oncogenic pathway [Garenski et al., 2009; Paik et al., 2011]. 


\begin{tabular}{|c|c|c|c|c|}
\hline N\# & prevalence & region & country & reference \\
\hline 10 & $8(80 \%)$ & LT, VP1 & USA & Feng et al., 2008 \\
\hline 13 & $7(54 \%)$ & LT, VP1 & USA & Ridd et al., 2008 \\
\hline 53 & $45(85 \%)$ & LT & Germany & Becker et al., 2009 \\
\hline 5 & $2(40 \%)$ & LT & the Netherlands & Wetzels et al., 2009 \\
\hline 31 & $24(77 \%)$ & LT & USA & Carter et al., 2009 \\
\hline 17 & $15(88 \%)$ & LT & USA & Busam et al., 2009 \\
\hline 23 & $17(74 \%)$ & st & USA & Bhatai et al., 2009 \\
\hline 9 & $8(89 \%)$ & LT, VP1 & France & Foulongne et al., 2008 \\
\hline 50 & $43(86 \%)$ & LT & Germany & Houben et al., 2010 \\
\hline 91 & $84(92 \%)$ & LT & Germany & Helmbold et al., 2009 \\
\hline 14 & $11(79 \%)$ & LT, VP1 & Japan & Nakajima et al., 2009 \\
\hline 7 & $6(86 \%)$ & LT, VP1 & USA & Loyo et al., 2010 \\
\hline 1 & $1(100 \%)$ & LT, VP1 & Switzerland & Mertz et al., 2010 \\
\hline 39 & $30(77 \%)$ & LT, VP1 & Germany & Kassem et al., 2008 \\
\hline 34 & $30(88 \%)$ & LT & Germany & Wieland et al., 2009 \\
\hline 5 & $5(100 \%)$ & LT & Germany & Wieland et al., 2009 \\
\hline 1 & $1(100 \%)$ & LT, VP1 & Switzerland & Mertz et al., 2010 \\
\hline 114 & $91(80 \%)$ & LT, VP1 & Finland & Sihto et al., 2009 \\
\hline 10 & $7(70 \%)$ & LT, VP2, & USA & Shuda et al., 2009 \\
\hline 1 & $1(100 \%)$ & LT & USA & Duncavage et al., 2009 \\
\hline 29 & $22(76 \%)$ & LT & USA & Duncavage et al., 2009 \\
\hline 5 & $5(100 \%)$ & LT & Finland & Koljonen et al., 2009 \\
\hline 16 & $11(69 \%)$ & LT & North America & Garenski et al., 2009 \\
\hline 21 & $5(24 \%)$ & LT & Australia & Garenski et al., 2009 \\
\hline 33 & $21(64 \%)$ & LT, st & Germany & Andres et al., 2009+2010 \\
\hline 11 & $6(55 \%)$ & LT, st, VP1-3 & Japan & Katano et al., 2009 \\
\hline 22 & $13(59 \%)$ & LT & USA & Paulson et al., 2009 \\
\hline 27 & $19(70 \%)$ & LT, VP1 & USA & Tolstov et al., 2009 \\
\hline 32 & $21(66 \%)$ & LT, VP, NCCR & France & Touzé et al., 2009 \\
\hline 10 & $10(100 \%)$ & LT, st, VP1 & France & Sastre-Garau et al., 2009 \\
\hline 7 & $5(89 \%)$ & LT, VP1 & Hungary & Varga et al., 2009 \\
\hline 2 & $2(100 \%)$ & LT1, LT3 & USA & Wu et al., 2010 \\
\hline 9 & $8(89 \%)$ & LT1, LT3, VP1 & France & Foulongne et al., 2008 \\
\hline 33 & $31(94 \%)$ & LT3, VP1 & France & Laude et al., 2010 \\
\hline 68 & $51(75 \%)$ & VP1 & France & Touzé et al.,2011 \\
\hline 27 & $19(70 \%)$ & LT & USA & Paulson et al., 2011 \\
\hline 32 & $24(75 \%)$ & LT and VP1 & Germany & Werling et al., 2011 \\
\hline 9 & $8(89 \%)$ & LT1,VP1 & Italy & Paolini et al., 2011 \\
\hline 26 & $20(77 \%)$ & LT, VP1 & Japan & Kuwamoto et al., 2011 \\
\hline 87 & $67(77 \%)$ & LT & Finland & Waltari et al., 2010 \\
\hline 44 & $29(66 \%)$ & LT, VP1 & Germany & Handschel et al., 2010 \\
\hline 6 & $4(67 \%)$ & LT & USA & Lewis et al., 2010 \\
\hline 13 & $7(54 \%)$ & LT, VP1 & USA & Ridd et al., 2009 \\
\hline 7 & $7(100 \%)$ & LT & South Korea & Woo, 2010 \\
\hline 3 & $2(67 \%)$ & LT & Germany & Schmitt et al., 2011 \\
\hline 91 & $71(78 \%)$ & LT & Finland & Sihto et al., 2011 \\
\hline$\Sigma=1198$ & $924(77 \%)$ & & & \\
\hline
\end{tabular}

Table 2. Prevalence of MCPyV DNA in MCC.\#N=number of patients. 
There is a slighter overall incidence of MCC among women than among men, while other studies found the opposite [Kaae et al., 2010; Calder \& Smoller, 2010]. Not all studies that have examined the presence of MCPyV DNA in MCC have specified the distribution of positive and negative samples among male and female patients. A compilation of published data reveals that the rate of MCPyV DNA positive MCCs in men is $78 \%(n=130)$, which is similar to women $(75 \% ; n=83)$. However, the investigation of only a limited number of patients urges the caution interpretation of the results [Becker et al., 2009; Wetzels et al., 2009; Bhatai et al., 2010; Foulongne et al, 2008; Nakajima et al., 2009; Mertz et al., 2010 a; Sihto et al., 2009; Koljonen et al., 2009; Katano et al., 2009; Paulson et al., 2009; Varga et al., 2009; Wu et al., 2010; Woo et al., 2010]. Only Sihto and colleagues screened a relative large cohort ( 80 men and 34 women) and they found that $84 \%$ of their male MCC patients were positive for MCPyV DNA against 71\% for the female MCC patients [Sihto et al., 2009]. A recent study by the same group on a Finnish cohort showed the opposite tendency [Sihto et al., 2011]. They found that the presence of LT-ag was associated with the female gender, but $70 \%(63 / 91)$ of their patients were female.

\section{Mechanisms for MCPyV-induced MCC}

\subsection{Expression of truncated LT-ag}

One of the criteria for a causal role of a virus in cancer is the requirement of expression of part of the viral genome to maintain the transformed state of the cell. This was originally proven by studies with Rous sarcoma virus carrying a temperature-sensitive mutation in the v-src gene and later confirmed for SV40 in a transgenic mouse model that allowed timely regulated doxycycline-dependent expression of LT-ag [Kawai \& Hanafusa; 1971; Friis et al., 1980; Ewald et al., 1996]. At the non-permissive temperature, the mutant Rous sarcoma virus was unable to induce or maintain morphological transformation of chick embryo cells, while cell transformation appeared when cultures were shifted to a permissive temperature [Kawai \& Hanafusa; 1971; Friis et al., 1980]. Turning on expression of SV40 LT-ag at birth, induced cellular transformation by 4 months of age. Silencing LT-ag for 3 weeks reversed the hyperplasia state. However, turning off LT-ag 7 months after birth did not abolish the hyperplasia, indicating that LT-ag was no longer required to maintain the transformed state [Ewald et al., 1996]. The observations that MCPyV positive MCC express LT-ag and that MCPyV positive MCC patients have much higher LT-ag seropositivity than non-MCC patients may indicate that the presence of this oncoprotein is involved in MCC [Shuda et al., 2009; Busam et al., 2009; Paulson et al., 2010; Houben et al, 2011; see Table 1]. This assumption is supported by results from knockdown studies in MCPyV positive MCC cell lines and a xeno-transplantation model, which illustrated that continuous expression of LTag and st-ag is required for cell proliferation and tumour progression [Houben et al., 2010; Houben et al., 2011].

Unexpectedly, MCPyV positive tumours express truncated LT-ag due to nonsense mutations or frame shift mutations generating premature stop codons (Figure 4; [Feng et al., 2008; Shuda et al., 2009; Duncavage et al., 2009a; Laude et al., 2010]). The mutation does not affect st-ag, but truncated LT-ag and 57kT become indistinguishable. The truncated LT-ag and $57 \mathrm{kT}$ proteins retain the DnaJ region and pRb-binding pocket, but lack the origin of replication- and the p53-binding domains, and the domains with helicase and ATPase activity. The fact that truncated LT-ag in MCC still can bind $\mathrm{pRb}$ and that loss of $\mathrm{pRb}$ is not a frequent occurrence in MCC suggests that inactivation of pRb through LT-ag binding is 
essential for MCPyV-mediated MCC tumorigenesis [Houben et al., 2009]. This prompted Houben and co-workers to examine the importance of LT-ag:pRb interaction in MCC. Specific knock down of LT-ag resulted in a marked growth inhibition and accumulation of MCPyC positive MCC cells in G1 phase of the cell cycle. The transformed phenotype was rescued by ectopic expression of LT-ag with an intact pRb motif, but not by LT-ag with a mutated pRb binding site [Houben et al., 2011]. These observations suggest that the LTag:pRb interaction is essential for tumour development.

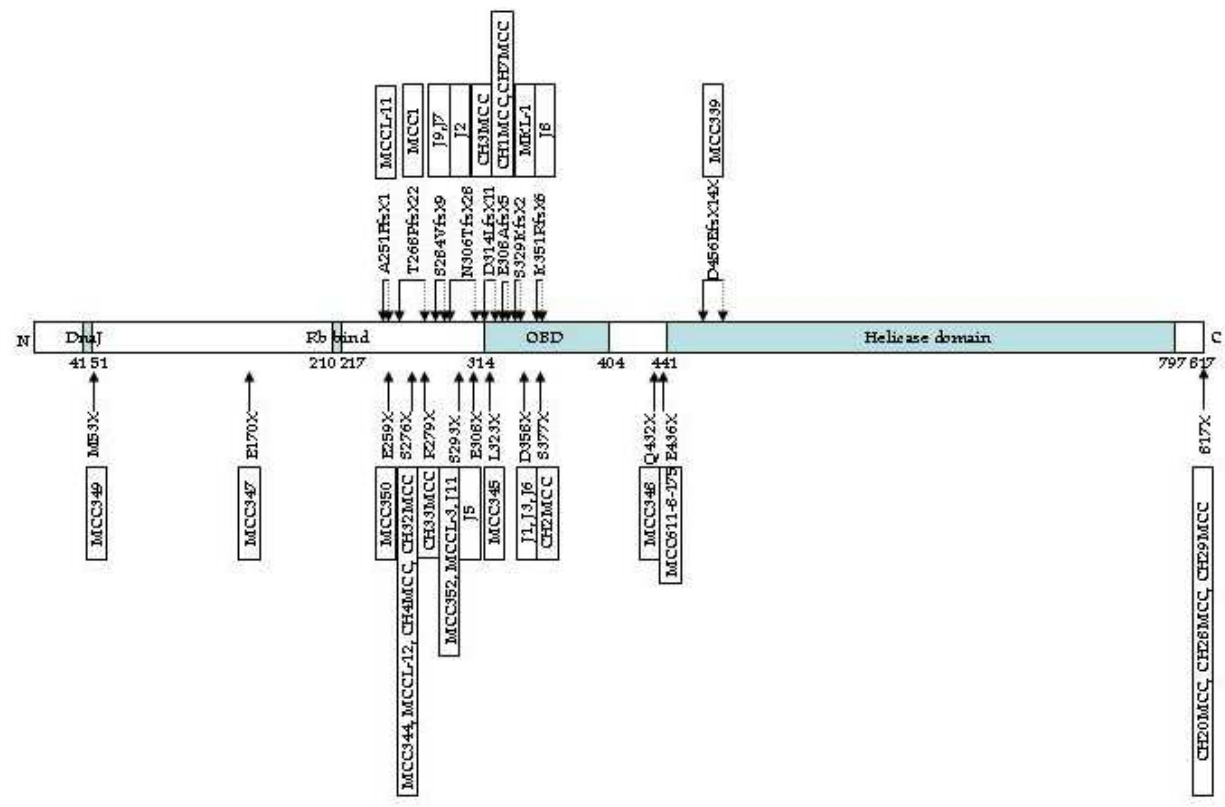

Fig. 4. Mutations causing truncation of LT-ag that have been reported in MCC [Feng et al., 2008; Fisher et al., 2010; Laude et al., 2010; Nakamura et al., 2010; Schrama et al., 2010 and MCC611-8-175 Genbank ACJ05659.1]. The arrows in the lower part of the figure represent the sites where nonsense mutations have occurred. The mutation of the amino acid into the corresponding nonsense codon (indicated by $\mathrm{X}$ ) is given. The double arrows at the top part of the figure symbolize the site of the mutation that causes the frame shift (first arrow) and the introduction of a stop codon due to this frame shift (second arrow). The X followed by a number indicates how many codons downstream of the frameshift a stopcodon is introduced. The functional DnaJ, pRb binding, origin binding domain (ODB) and helicase domains are indicated and the numbers beneath the domains represent the amino acid residues of the beginning and the end of the respective domains. The name of the reported strain is encompassed in a rectangle.

Skin MCPyV isolates obtained from 14 different healthy subjects encoded full-length open reading frames for predicted viral proteins, including LT-ag [Schowalter et al., 2010]. Thus, in contrast to MCC, normal skin tissue seems to be infected with MCPyV encoding fulllength LT-ag. Sequencing a full-length MCPyV genome from a Kaposi's sarcoma case revealed that the LT-ag gene would produce a truncated form of the protein [Katano et al., 
2009]. This example illustrates that expression of truncated LT-ag is not restricted to MCC, but can occur in other malignancies. Whether $\mathrm{MCPyV}$ infection is a risk for Kaposi's sarcoma remains elusive.

The truncated LT-ag mutant proteins identified in MCC are deprived of their DNA helicase activity and consequently unable to sustain viral DNA replication [Shuda et al., 2009]. This may prevent virus production and eventually lysis of the infected cells and is thus incompatible with expansion of the virus-infected cell [Houben et al., 2009]. Replication deficient MCPyV may persist in the host cell without causing destruction of the infected cell. The truncated LT-ag, however, retains its oncogenic potentials and this may lead to transformation of the infected cell. This finding is reminiscent with early observations that revealed that replication-deficient SV40 or SV40 encoding LT-ag defective in origin-binding displayed elevated transforming potentials compared to wild-type virus [reviewed in zur Hausen, 2008b]. Furthermore, studies with transgenic mice expressing SV40 LT-ag showed that a C-terminal truncated LT-ag variant that still can bind $\mathrm{pRb}$, but lacks its helicase domain retains its transforming property [Rathi et al., 2009]. Hence, expression of a SV40 truncated LT-ag mutant with similar functions as MCPyV LT-ag variants described in MCC induced hyperplasia and eventually dysplasia. This observation suggests that a similar mechanism may be operational in MCPyV positive MCC.

\subsection{Mutations in st-ag in MCC}

So far, no mutations in st-ag expressed in MCC have been reporter. One normal skin isolate (9b) had a single base-pair insertion in the C-terminal part of st-ag causing a premature stop codon resulting in truncation of the last 15 amino acids, but the functional implication for this mutation has not been examined [Schowalter et al., 2010]. The corresponding residues in SV40 st-ag are not necessary for the interaction with PP2A, suggesting that this MCPyV st-ag mutant still can interact with PP2A [Mateer et al., 1998]. Interestingly, the transcript levels of st-ag, but not LT-ag or VP1 in the skin of a healthy woman containing episomal MCPyV DNA increased following solar UV-irradiation administration [Mogha et al., 2010]. Because the LT-ag and st-ag transcripts are generated from the same unspliced precursor, a post-transcriptional mechanism may be operational such as at the splicing level to generate different amounts of LT- and st-ag transcripts. Alternatively UV-light may activate pathways that control the decay of LT-ag and st-ag mRNA differently [Bollig et al., 2002].

\subsection{Polymorphism in the non-coding control region (NCCR)}

Previous studies with the human polyomaviruses BKPyV and JCPyV revealed that variation in the NCCR affects their transforming properties [Moens et al., 1995; Ricciardiello et al., 2001]. Thus, increased promoter activity of MCPyV variants may result in enhanced levels of the oncoproteins LT-ag, 57kT and st-ag or/and stimulate the expression of cellular genes in the vicinity of integrated viral genome. Mutations that increase the intrinsic activity of the MCPyV NCCR may affect the oncogenic potential of the virus and therefore be a hallmark for MCC-derived virus isolates. So far, the genomes of tumour-derived MCPyV and isolates from non MCC patients display little variation in their NCCR [Feng et al., 2008; Touzé et al., 2009; Kwun et al., 2009; Pastrana et al., 2009]. The tumour-derived MCPyV isolate MCC350 contains the 5 base-pair deletion GAGTT in its regulatory region compared to the MCC339 strain [Feng et al., 2008]. This deletion was also detected in MCPyV isolates from 5 out of 7 French MCC patients [Touzé et al., 2009], in the MCVw156 strain and the TKS MCPyV DNA 
isolated from a from Kaposi's sarcoma. The latter had a 25 base pair tandem repeat in its NCCR duplicating a motif that stimulates transcription and in vitro replication of SV40 and JCPyV [Martin et al., 1985; Katano et al., 2009]. However, an isolate (isolate 16b) obtained from skin swabs of a healthy person contained the same duplication, showing that this feature is not restricted to MCPyV present in malignant tissue [Schowalter et al., 2010]. So far, there is no indication that a specific NCCR is associated with MCPyV in MCC.

\subsection{Integrational inactivation}

Chromosomal integration is a characteristic of viruses causing cancer in humans [Matsuoka \& Jeang, 2007; zur Hausen, 2009; Tsai \& Chung, 2010]. Integration may cause disruption of genes, creating viral-cellular fusion proteins or altered expression of cellular protooncogenes or tumour suppressor genes. These events might be oncogenic. MCPyV genomes are clonally integrated into the DNA of the primary MCC tumour cells and their metastatic cells, suggesting that integration occurred before clonal expansion [Feng et al., 2008; Duncavage et al., 2009a]. The viral DNA seems to be integrated at different locations within the cellular genome in different MCC tumours and MCC cell lines examined [Feng et., 2008; Sastre-Garau et al., 2009; Laude et al., 2010]. The first report on MCPyV in MCC showed integration on chromosome 3 p14.2, in intron 1 of the receptor tyrosine phosphatase type $G$ $(P T P R G)$ gene, a gene identified as a putative tumour suppressor gene [Feng et al., 2008]. Table 3 summarizes other identified integration sites. The functional implication in tumorigenesis is not known because no altered gene expression related to $\mathrm{MCPyV}$ insertion was monitored [Sastre-Garau et al., 2009]. The virus host junction can occur in VP1, NCCR, and in the 3' part of LT-ag [Feng et al., 2008; Sastre-Garau et al., 2009; Laude et al., 2010].

\begin{tabular}{|c|c|c|c|}
\hline insertion & putative target gene & link to cancer & reference \\
\hline $2 q 32.3$ & not determined & & Sastre-Garau et al., 2009 \\
\hline 3p14.2 & $\begin{array}{l}\text { receptor tyrosine } \\
\text { phosphatase type G }\end{array}$ & tumour suppressor & Feng et al., 2008 \\
\hline $3 q 26.33$ & ATP1-1B & & Sastre-Garau et al., 2009 \\
\hline $4 q 13.1$ & SRD5A2L2 & & Sastre-Garau et al., 2009 \\
\hline $5 q 35.1$ & TLX3 & & Sastre-Garau et al., 2009 \\
\hline $6 q 23.3$ & IL20RA & lung carcinogenesis & Sastre-Garau et al., 2009 \\
\hline $6 \mathrm{p} 24$ & $\begin{array}{c}\text { GDP-mannose } 4,6 \\
\text { dehydratase }\end{array}$ & $\begin{array}{l}\text { fucosylation in colon } \\
\text { cancer }\end{array}$ & Laude et al., 2010 \\
\hline $8 q 24.21$ & MYC & Proto-oncogene & Sastre-Garau et al., 2009 \\
\hline $9 q 33$ & $\begin{array}{l}\text { DENN/MADD domain } \\
\text { containing } 1 \mathrm{~A} \text { isoform } 1\end{array}$ & & Laude et al., 2010 \\
\hline $11 \mathrm{p} 15$ & Parvin- $\alpha$ & adhesion and motility & Laude et al., 2010 \\
\hline $11 \mathrm{p} 15$ & TEF-1/TEAD1 & & Laude et al., 2010 \\
\hline $12 q 23.1$ & AX747640 & & Sastre-Garau et al., 2009 \\
\hline $15 q 14$ & $\begin{array}{l}\text { ATP binding domain } 4 \\
\text { isoform } 2\end{array}$ & & Laude et al., 2010 \\
\hline $20 q 11.21$ & SNTA1 & & Sastre-Garau et al., 2009 \\
\hline Yq12 & not determined & & Sastre-Garau et al., 2009 \\
\hline
\end{tabular}

Table 3. Chromosomal integration sites of MCPyV. 
Several groups reported that MCPyV DNA is not exclusively integrated in MCC, but may also exist episomal. Wetzels and her colleagues could demonstrate the presence of viral particles in one of their MCC samples by electron microscopy, suggesting non-integrated viral DNA. Wetzels did not examine whether integrated viral DNA was present in the MCC sample that contains virus particles [Wetzels et al., 2009]. Sastre-Garau and co-workers characterized one MCC case where the tumour cells contained both integrated and episomal MCPyV DNA [Sastre-Garau et al., 2009]. Laude and co-workers also found MCC containing $\mathrm{MCPyV}$ encoding full-length LT-ag. They reported the coexistence of integrated concatemers or latent episomes of $\mathrm{MCPyV}$ genome and truncated integrated viral sequences in five MCC cases [Laude et al., 2010]. The presence of virions indicates active viral replication and therefore a LT-ag that can sustain viral DNA replication, i.e. LT-ag that possesses helicase activity. Because integration and truncated LT-ag expression are hallmarks of MCPyV-positive MCC, it is possible that in MCC containing only episomal viral DNA, that the virus was merely a fortuitous co-inhabitant of the tumour cells.

\subsection{MyCPyV and cellular miRNA expression}

Viral infections can cause altered expression patterns of miRNA in the host cell because viral-encoded miRNA or/and viral proteins can target cellular miRNA/targetome pathways, thereby contributing to the oncogenic properties of viruses [Skalsky \& Cullen, 2010; Lin \& Flemington, 2011]. MiRNA are generated by RNA polymerase II and HPyV LTag and st-ag have been shown to affect the expression of many genes, including RNA polymerase II transcribed genes [Moens et al., 1997; Klein et al., 2005; Deeb et al., 2007]. It is not known whether MCPyV infection or expression of its LT-ag or/and st-ag results in altered expression of cellular miRNA, but SV40 st-ag enhances expression of miR-27a in a PP2A-dependent manner and contributes to the malignant transformation of human bronchial epithelial cells. The transcript encoding the cell-cycle progression protein Fbxw7 was a target for miR-27a. Thus, promotion of cell growth through the suppression of Fbxw7 by st-ag-induced miR-27a overexpression may play a role in malignant transformation [Wang et al., 2011]. Profiling miRNA in MCPyV positive and negative MCC may indicate whether altered cellular miRNA expression is a co-mechanism in MCC pathogenesis.

\section{Therapy}

Currently, there is no specific treatment for MCC. Local excision of the tumour combined with radiation therapy and chemotherapy is the most common protocol [Tai, 2008; Ramahi et al., 2011]. Because of the high association rate of MCPyV with MCC, antiviral-specific therapy may form an attractive therapy for MCC. Although a few clinical trials with MCC were started or are in progress [ClinicalTrials.gov], none of them are specifically aimed at targeting MCPyV. Vaccination is an encouraging possibility in light of the success with the oncoviruses such as hepatitis B virus and high-risk human papillomaviruses. To begin to explore the idea of a MCPyV vaccine, Pastrana and her collaborators immunized mice with virus-like particles (VLP) composed of MCPyV VP1 and VP2. All vaccinated animals generated strong neutralizing antibodies. In fact the titres were comparable to the titres of animals challenged with human papillomavirus VLP and higher than animals injected with JCPyV VLP. Thus, MCPyV VLP appears to be a strong immunogen and thus a promising vaccine candidate [Pastrana et al., 2009]. One case report describes that subcutaneous administration of $3,000,000$ IU of interferon- $\beta$ (IFN- $\beta$ ) per day to a Japanese 62-year-old 
woman with MCPyV positive MCC resulted into a beneficial response after 3 weeks with complete remission that continued for more than 8 years [Nakajima et al., 2009]. IFN- $\alpha$ could induce apoptosis of MCC-1 cell lines in vitro, but its effect on patients was not tested [Krasagakis et al., 2008]. These results suggest that interferons may be useful in MCC therapy. Other feasible approaches are disruptor molecules, antiviral drugs and RNA interference. Continuous expression of LT-ag with an intact $\mathrm{pRb}$ binding site is required to maintain the transformed phenotype of MCC. Molecules disrupting $p R b$ :LT-ag interactions may possess low off-target effects and therefore be an attractive strategy for future MCC therapy [Houben et al., 2011]. Similarly, disruptors of the Dna J domain may be applied. Antiviral drugs that interfere with the different stages of the life cycle of MCPyV may prevent virus spread after primary infection, but no such drugs are currently available and it is very unrealistic to establish the time point of primary infection in individuals. SiRNAmediated knock down of MCPyV LT-ag expression may be another therapeutic approach. Eliminating LT-ag expression in MCCs may therefore be sufficient to reverse the malignant cell to a more benign cell or trigger cell death as demonstrated in MCC cell lines [Houben et al., 2010]. It was shown that JCPyV- and BKPyV-encoded miRNA target ULBP3, a ligand for the natural killer cell receptor NKG2D, thereby protecting BKPyV/JCPyV infected cells from destruction [Bauman et al., 2011]. It is not known whether MCPyV miRNA exerts the same function, but if so, anti-miRNA against the MCPyV-encoded miRNA will maintain the ULBP3 expression levels in viral infected cells and will stimulate their elimination by natural killer cells.

\section{Conclusions and future perspectives}

Several findings underscore a causal role for MCPyV in MCC. The viral genome load and prevalence of MCPyV DNA are significantly higher in MCC than in other MCPyV infected tissues, in contrast to non-MCC tissue, the viral genome in MCC is integration and expresses truncated LT-ag that cannot sustain viral replication, but still interacts with $\mathrm{pRb}$. In accordance with other tumour viruses, there seems to be a very long incubation time between viral infection and development of the tumour because primary infection can occur in early childhood, but MCC is extremely unusual before the age of 50 . These observations suggest that additional events (e.g. skin exposure to UV-light, gender, perturbation of the immune system, co-infection other viruses, ethnicity, mutations in cellular genome) are required for MCC-induced malignancy. The absence of $\mathrm{MCPyV}$ in about $20 \%$ of $\mathrm{MCC}$ indicates the existence of $\mathrm{MCPyV}$-independent pathogenic pathways in this malignancy. This is supported by the finding that $\mathrm{MCPyV}$ seems to be associated with classic, but not variant MCC cell lines and that MCC display chromosomal abnormalities with loss of heterozygocity of chromosome $1 \mathrm{p}$ being the most common [Shuda et al., 2008; Leonard et al., 2000]. Alternatively, MCPyV may initiate neoplastic events, but the continuous presence of the virus is not required explaining why no traces of the virus can be detected in some of the MCC ('hit-and-run' hypothesis). The fact that MCPyV DNA is detected in many different tissues both in healthy individuals and in different patient groups raises the question whether MCPyV may be involved in other malignancies or diseases. The connection of MCPyV DNA in other tissues is not as strong as MCPyV and MCC and the state of the viral genome (episomal or integrated) and the mutational analysis of LT-ag have not been meticulously examined [reviewed in Moens et al., 2010]. World-wide studies are warranted to determine the possible association of $\mathrm{MCPyV}$ with other malignant and non- 
malignant diseases. Other important information that should be acquired includes determining the integration sites and the consequences on viral and cellular gene expression, and does miRNA expression pattern in $\mathrm{MCPyV}$ positive versus $\mathrm{MCPyV}$ negative MCC differ and if so, are these differences provoked by the virus and are they contributing to MCC pathogenesis? Besides these cancer-related issues, other fundamental issues such as route of infection, cell tropism and transmission need to be studied.

\section{References}

Abend, J.R.; Jiang, M. \& Imperiale, M.J. (2009). BK virus and human cancer: innocent until proven guilty. Seminars in Cancer Biology, Vol. 19, No. 4 (August 2004), pp. 252-260, ISSN 1044-579X

Albores-Saavedra, J.; Batich, K.; Chable-Montero, F.; Sagy, N.; Schwartz, A.M. \& Henson, D.E. (2009). Merkel cell carcinoma demographies, morphology, and survival based on 3870 cases: a population based study. Journal of Cutaneous Pathology, Vol. 37, No. 1 (January 2009), pp. 20-27, ISSN 0303-6987

Allander, T.; Andreasson, K.; Gupta, S.; Bjerkner, A.; Bogdanovic, G.; Persson, M.A.; Dalianis, T., Ramqvist, T. \& Andersson, B. (2007). Identification of a third human polyomavirus. Journal of Virology, Vol. 81, No. 8, (April 2007), pp. 4130-4136 ISSN 0022-538X

Andres, C.; Belloni, B.; Puchta, U.; Sander, C.A. \& Flaig, M.J. (2010). Prevalence of MCPyV in Merkel cell carcinoma and non-MCC tumors. Journal of Cutaneous Pathology, Vol. 37, No. 1, (January 2010), pp. 28-34, ISSN 0303-6987

Andres, C.; Belloni, B. \& Flaig, M.J. (2011). Value of Merkel cell Polyomavirus DNA Detection in Routine Pathology. American journal of dermatopathology, Vol. 33, No. 3 (May 2011), pp. 329-330, ISSN 0193-1091

Asioli, S.; Righi, A.; Volante, M.; Eusebi, V. \& Bussolati, G. (2007). P63 expression as a new prognostic marker in Merkel cell carcinoma. Cancer, Vol. 110, No.3 (Augustus 2007), pp. 640.647, ISSN 1097-0142

Babakir-Mina, M.; Ciccozzi, M.; Lo Presti, A.; Greco, F.; Perno, C.F. \& Ciotti, M. (2010). Identification of Merkel cell polyomavirus in the lower respiratory tract of Italian patients. Journal of Medical Virology, Vol. 82, No. 3 (March 2010), pp. 505-509, ISSN 1096-9071

Barzon, L.; Squarzon, L.; Militello, V.; Trevisan, M.; Porzionato, A.; Macchi, V.; De Caro, R. \& Palù, G. (2009). WU and KI polyomaviruses in the brains of HIV-positive patients with and without progressive multifocal leukoencephalopathy. Journal of Infectious Diseases, Vol. 200, No. 11 (December 2009), pp. 1755-1758, ISSN 0022-1899

Bauman, Y.; Nachmani, D.; Vitenshstein, A.; Tsukerman, P.; Drayman, N.; Stern-Ginossar, N.; Lankry, D.; Gruda, R. \& Mandelboim, O. (2011). An identical miRNA of the human JC and BK polyomaviruses targets the stress-induced lignad ULBP3 to escape immune elimination. Cell Host Microbe, Vol. 9, No. 2 (February 2011), pp. 93102, ISSN 1931-3128

Becker, J.C.; Schrama, D. \& Houben, R. (2009). Merkel cell carcinoma. Cellular and Molecular Life Sciences, Vol. 66, No. 1 (January 2009), pp. 1-8, ISSN 1420-682X

Bhatia, K.; Goedert, J.J.; Modali, R.; Preiss, L. \& Ayers, L.W. (2010). Immunological detection of viral large $\mathrm{T}$ antigen identifies a subset of Merkel cell carcinoma tumors with 
higher viral abundance and better clinical outcome. International Journal of Cancer, Vol. 127, No. 6 (September 2010), pp. 1493-1496, ISSN 1097-0215

Bialasiewicz, S.; Lambert, S.B.; Whiley, D.M.; Nissen, M.D. \& Sloots, T.P. (2009). Merkel cell polyomvirus DNA in respiratory speciments from children and adults. Emerging Infectious Diseases, Vol. 15, No. 3 (March 2009), pp. 492-494, ISSN 1080-6059

Bofill-Mas, S.; Rodriguez-Manzano, J.; Calgua, B.; Carratala, A. \& Girones, R. (2010). Newly descrive human polyomaviruses Merkel cell, KI and WU are present in urban sewage and may represent potential enviromental contaminants. Virology Journal, Vol.7(June 2010), pp. 141-146, ISSN 1743-422X

Bollig, F.; Winzen, R; Kracht, M.; Ghebremedhin, B.; Ritter, B.; Wilhelm, A.; Resch, K. \& Holtmann, H. (2002). Evidence for general stabilization of mRNAs in response to UV light. European Journal of Biochemistry, Vol. 269, No. 3 (December 2002), pp. 5830-5839, ISSN 0014-2956

Boulais, N. \& Misery, L. (2007). Merkel cells. Journal of the American Academy of Dermatology, 57, No. 1 (July 2007), pp. 147-165, ISSN 0190-9622

Busam, K.J.; Jungbluth, A.A.; Rekthman, N.; Coit, D.; Pulitzer, M.; Bini, J.; Arora, R.; Hanson, N.C.; Tassello, J.A.; Frosina, D.; Moore, P. \& Chang, Y. (2009). Merkel cell polyomavirus expression in Merkel cell carcinomas and its absence in combined tumors and pulmonary neuroendocrine carcinomas. The American Journal of Surgical Pathology, Vol. 33, No. 9 (September 2009), pp. 1378-1385, ISSN 01475185

Calder, K.B. \& Smoller, B.R. (2010). New insights into Merkel cell carcinoma. Advances in Anatomic Pathology, Vol. 17, No. 3 (May 2010), pp. 155-161, ISSN 1072-4109

Campello, C.; Comar, M.; D’Agaro, P.; Minicozzi, A.; Rodella, L. \& Poli, A. (2011). A molecular case-control study of the Merkel cell polyomavirus in colon cancer. Journal of Medical Virology, Vol. 83, No. 4 (April 2011), pp. 721-724, ISSN 1096-9071

Carter, J.J.; Paulson, K.G.; Wipf, G.C.; Miranda, D.; Madeleine, M.M.; Johnson, L.G.; Lemos, B.D.; Lee, S.; Warcola, A.H.; Iyer, J.G.; Nghiem, P. \& Galloway, D.A. (2009) Association of Merkel Cell polyomavirus-specific antibodies with Merkel cell carcinoma. Journal of the National Cancer Institute, Vol. 1001, No. 21 (November 2009), pp.1510-1522 ISSN 0027-8874

Carswell, S. \& Alwine, J.C. (1986). Simian virus 40 facilitates perinuclear-nuclear localization of VP1, the major capsid protein. Journal of Virology, Vol. 204, No. 1 (July 1986), pp. 1055-1061, ISSN 0022-538X

Chen, T.; Hedman, L.; Mattila, P.S.; Jartti, T.; Ruuskanenc O.; Söderlund-Venermoa, M. \& Hedman K. (2011). Serological evidence of Merkel cell polyomavirus primary infections in childhood. Journal of Clinical Virology, Vol. 50 No. 2 (February 2011), pp. 125-129, ISSN 1386-6532

ClinicalTrials.gov

Daniels, R.; Sadowicz, D. \& Hebert, D.N. (2007). A very late viral protein triggers the release of SV40. PloS Pathogens, Vol. 3, No. 7 (July 2007), pp. e98, ISSN 1553-7366

Darbinyan, A.; Darbinian, N.; Safak, M.; Radhakrishnan, S.; Giordano, A. \& Khalili, A. (2002). Evidence for dysregulation of cell cycle by human polyomavirus, JCV, late auxiliary protein. Oncogene, Vol. 21, No. 36 (Augustus 2002), pp. 5574-5581, ISSN 0950-9232 
Darbinyam, A.; Siddiqui, K.M.; Slonina, D.; Darbinian, N.; Amini, S.; White, M.K. \& Khalili, K. (2004). Role of JC virus agnoprotein in DNA repair. Journal of Virology, Vol. 78, No. 16 (Augustus 2004), pp. 8593-8600, ISSN 0022-538X

DeCaprio, J.A. (2009). Does detection of Merkel cell polyomavirus in Merkel cell carcinoma provide prognostic information? Journal of the National Cancer Institute, Vol. 101, No. 13 (July 2009), pp. 905-907, ISSN 0027-8874

Deeb, K.K.; Michalowska, A.M.; Yoon, C.Y.; Krummey, S.M.; Hoenerhoff, M.J.; Kavanaugh, C.; Li, M.C.; Demayo, F.J.; Linnoila, I.; Deng, C.X.; Lee, E.Y.H.P.; Medina, D.; Shih, J.H. \& Green, J.E. (2007). Identification of an integrated SV40 T7t-antigen cancer signature in aggressive human breast, prostate, and lung carcinomas with poor prognosis. Cancer Research, Vol. 67, No. 17 (September 2007), pp. 8065-8080, ISSN $1538-7445$

Duncavage, E.J.; Le, B.M.; Wang, D. \& Pfeifer, J.D. (2009a). Merkel cell polyomavirus: a specific marker for merkel cell carcinoma in histologically similar tumors. American Journal of Surgical Patholology, Vol. 33, No. 12 (December 2009), pp. 1771-1777, ISSN 01475185

Duncavage, E.J.; Zehnbauer, B.A. \& Pfeifer, J.D. (2009b). Prevalence of Merkel cell polyomavirus in Merkel cell carcinoma. Modern Pathology, Vol.22, No. 4, (April 2009), pp.516-521, ISSN 0893-3952

Dworkin, A.M.; Tseng, S.Y.; Allain, D.C.; Iwenofu, O.H.; Peters, S.B. \& Toland, A.E. (2009). Merkel cell polyomavirus in cutaneous squamous cell carcinoma of immunocompetent individuals. Journal of Investigative Dermatology, Vol. 129, No. 12 (December 2009), pp. 2868-2874, ISSN 0022-202X

Ewald, D.; Li, M.; Efrat, S.; Auer, G.; Wall, R.J.; Furth, P.A. \& Hennighausen L. (1996). TimeSensitive Reversal of Hyperplasia in Transgenic Mice Expressing SV40 T Antigen. Science, Vol. 273, No. 5280 (September 1996), pp. 1384-1386, ISSN 0036-8075

Engels, E.A.; Biggar, R.J.; Hall, H.I.; Cross, H.; Crutchfield, A.; Finch, J.L.; Grigg, R.; Hylton, T.; Pawlish, K.S.; McNeel, T.S. \& Goedert, J.J. (2008). Cancer risk in people infected with human immunodeficiency virus in the United States. International Journal of Cancer, Vol. 123, No. 1 (July 2008), pp. 187-194, ISSN 1097-0215

Erickson, K.D.; Garcea, R.L. \& Tsai, B. (2009). Ganglioside GT1b is a putative host cell receptor for the Merkel cell polyomavirus. Journal of Virology, Vol. 83, No. 19 (October 2009), pp. 10275-10279, ISSN 0022-538X

Faust, H.; Pastrana, D.V.; Buck, C.B.; Dillner, J. \& Ekström, J. (2011). Antibodies to Merkel cell polyomavirus correlate to presence of viral DNA in the skin. Journal of Infectious Diseases, Vol. 203, No. 8 (April 2011), pp. 1096-1100, ISSN 0022-1899

Feinmesser, M.; Halpern, M.; Fenig, E.; Tsabari, C.; Hodak, E.; Sulkes, J.; Brenner, B. \& Okon, E. (1999). Expression of the apoptosis-related oncogenes bcl-2, bax, and p53 in Merkel cell carcinoma. Can they predict treatment response and clinical outcome? Human Pathology, Vol. 30, No. 11 (November 1999), pp. 1367-1372, ISSN 0046-8177

Feng, H.; Shuda, M.; Chang, Y. \& Moore, P.S. (2008). Clonal integration of a polyomavirus in human Merkel cell carcinoma. Science, Vol. 319, No. 5866 (February 2008), pp. 10961100, ISSN 0036-8075

Fischer, N.; Brandner, J.; Fuchs, F.; Moll, I. \& Grundhoff, A. (2010) Detection of Merkel cell polyomavirus (MCPyV) in Merkel cell carcinoma cell lines: cell morphology and 
growth phenotype do not reflect presence of the virus. International Journal of Cancer, Vol. 126, No. 9 (May 2010), pp. 2133-2142, ISSN 1097-0215

Foulongne, V.; Kluger, N.; Dereure, O.; Brieu, N.; Guillot, B. \& Segondy, M. (2008). Merkel cell polyomavirus and Merkel cell carcinoma, France. Emerging Infectious Diseases. Vol. 14, No. 9 (September 2008), pp. 1491-1493, ISSN 1080-6059

Foulongne, V. ; Kluger, N. ; Dereure, O. ; Mercier, G. ; Molès, J.P. ; Guillot, B. \& Segondy, M. (2010a). Merkel cell polyomavirus in cutaneous swabs. Emerging Infectious Diseases, Vol. 16, No. 4 (April 2010), pp. 685-687, ISSN 1080-6059

Foulongne, V.; Dereure, O.; Kluger, N.; Molès, J.P.; Guillot, B. \& Segondy, M. (2010b). Merkeld cell polyomavirus DNA detection in lesional and nonlesional skin from patients with Merkel cell carcinoma or other skin diseases. British Journal of Dermatology, Vol. 162, No. 1 (January 2010), pp. 59-63, ISSN 0007-0963

Friis, R.R.; Jockusch, B.M.; Boschek, C.B.; Ziemiecki, A.; Rübsamen, H. \& Bauer, H. (1980). Transformation-defective, temperature-sensitive mutants of Rous sarcoma virus have areversibly defective src-gene product. Cold Spring Harbor Symposia on Quantitative Biology, Vol. 44, No. 2, pp. 1007-1012, ISSN 0091-7451

Gardner, S.D.; Field, A.M.; Coleman, D.V. \& Hulme, B. (1971). New human papovavirus (B.K.) isolated from urine after renal transplantation. Lancet Vol.1, No. 7712, (June 1971), pp. 1253-1257, ISSN 0140-6736

Garneski, K.M.; Warcola, A.H.; Feng, Q.; Kiviat, N.B.; Leonard, J.H. \& Nghiem, P. (2009). Merkel cell polyomavirus is more frequently present in North American than Australian Merkel cell carcinoma tumors. Journal of Investigative Dermatology, Vol. 129 No. 1 (January 2009), pp. 246-248, ISSN 0022-202X

Gaynor, A.M.; Nissen, M.D.; Whiley D.M.; Mackay, I.M.; Lambert S.B.; Wu, G.; Brennan, D.C.; Storch, G.A.; Sloots, T.P. \& Wang, D. (2007). Identification of a novel polyomavirus from patients with acute respiratory tract infections. PLoS Pathogens, Vol. 3, No. 5 (May 2007), pp. e64, ISSN 1553-7366

Giraud, G.; Ramqvist, T.; Ragnarsson-Olding, B. \& Dalianis, T. (2008). DNA from BK virus and JC virus and from KI, WU, and MC polyomaviruses as well as from SV40 is not detected in non-UV-light associated primary malignant melanomas of mucous membranes. Journal of Clinical Microbiology, Vol. 46, No. 11 (November 2008), pp. 3595-3598, ISSN 0095-1137

Giraud, G.; Ramqvist, T.; Pastrana, D.V.; Pavot, V.; Lindau, C.; Kogner, P.; Orrego, A.; Buck, C.B.; Allander, T.; Holm, S.; Gustavsson, B. \& Dalianis, T. (2009). DNA from KI, WU and Merkel cell polyomaviruses is not detected in childhood central nervous system tumours or neuroblastomas. PLoS One, Vol. 4, No. 12 (December 2009), pp. e8239; ISSN 1932-6203.

Gjoerup, O. \& Chang, Y. (2010). Update on human polyomaviruses and cancer. Advances in Cancer Research, Vol. 106, No. pp. 1-51, ISSN 0065-230X

Goh, S.; Lindau, C.; Tiveljung-Lindell, A. \& Allander, T. (2009). Merkel cell polyomavirus in respiratory tract secretions. Emerging Infectious Diseases, Vol. 15, No. 3 (March 2009), pp. 489-491, ISSN 1080-6059

Gould, V.E.; Moll, R.; Moll, I.; Lee, I. \& Franke, W.W. (1985). Neuroendocrine (Merkel) cells of the skin: hyperplasias, dysplasias, and neoplasms. Laboratory Investigation, Vol. 52, No. 4 (April 1985), pp. 334-353, ISSN 0023-6837 
Handschel, J.; Müller, D.; Depprich, R.A.; Ommerborn, M.A.; Kübler, N.R.; Naujoks, C.; Reifenberger, J.; Schäfer, K.L. \& Braunstein, S. (2010). The new polyomavirus $(\mathrm{MCPyV})$ does not affect the clinical course in MCCs. International Journal of Oral and Maxillofacial Surgery, Vol. 39, No. 11, (November 2010), pp. 1086-1090, ISSN 0901-5027

Helmbold, P.; Lahtz, C.; Enk, A.; Herrmann-Trost, P.; Marsch W.C.; Kutzner, H. \& Dammann, R.H. (2009). Frequent occurrence of RASSF1A promoter hypermethylation and Merkel cell polyomavirus in Merkel cell carcinoma. Molecular Carcinogenesis, Vol. 48, No. 10 (October 2009), pp. 903-909, ISSN 1098-2744

Heymann, W.R. (2008). Merkel cell carcinoma: insights into pathogenesis. Journal of the American Academy of Dermatology, Vol. 59, No. 3 (September 2008), pp. 503-504, ISSN 0190-9622

Hodgson, N.C. (2005). Merkel cell carcinoma: changing incidence trends. Journal of Surgical Oncology, Vol. 89, No. 1 (January 2005), pp. 1-4, ISSN 1591-1063

Houben, R.; Schrama, D. \& Becker, J.C. 2009. Molecular pathogenesis of Merkel cell carcinoma. Experimental Dermatology, Vol. 18, No.3 (March 2009), pp. 193-198, ISSN 0906-6705

Houben, R.; Shuda, M.; Weinkam, R.; Schrama, D.; Feng, H.; Chang, Y.; Moore, P.S. \& Becker, J.C. (2010). Merkel cell polyomavirus-infected Merkel cell carcinoma cells require expression of viral T antigens. Journal of Virology, Vol. 84, No. 14 (July 2010), pp. 7064-7072, ISSN 0022-538X

Houben, R.; Adam, C.; Baeurle, A.; Hesbacher, S.; Grimm, J.; Angermeyer, S.; Henzel, K.; Hauser, S.; Elling, R.; Bröcker, E.B.; Gaubatz, S.; Becker, J.C. \& Schrama, D. (2011). An intact retinoblastoma protein binding site in Merkel cell polyomavirus large $\mathrm{T}$ antigen is required for promoting growth of Merkel cell carcinoma cells. International Journal of Cancer, March 16 [Epub ahead of print].

Husseiny, M.I.; Anastasi, B.; Singer, J. \& Lacey, S.F. (2010). A comparative study of Merkel cell, BK and JC polyomavirus infections in renal transplant recipients and healthy subjects. Journal of Clinical Virology, Vol. 49, No. 2 (October 2010), pp. 137-140, ISSN 1386-6532

Imperiale, M.J. \& Major EO. (2007). Polyomaviridae, In: Fields Virology, 5th edition; Knipe, D.M., Howley, P.M., Griffin, D.E., Lamb, R.A., Martin, M.A., Roizman, B., \& Straus, S.E., pp. 2263-2298, Lippincott Williams and Wilkins, ISBN 10:02-7817-6060-7, Philadelphia.

Jiang, M.; Abend, J.R.; Johnson, S.F. and Imperiale, M.J. 2009. The role of polyomaviruses in human diseases. Virology, Vol. 384, No. 2, (February 2009), pp. 266-273 ISSN 00426822

Johannessen, M.; Myhre, M.R.; Dragset, M.; Tümmler, C. \& Moens, U. (2008). Phosphorylation of human polyomavirus BK agnoprotein at Ser-11 is mediated by PKC and has an important regulative function. Virology, Vol. 379, No. 1 (September 2008), pp. 97-109, ISSN 0042-6822

Johne, R.; Buck, C.B.; Allander, T.; Atwood, W.J.; Garcea, R.L.; Imperiale, M.J.; Major, E.O.; Ramqvist, T. \& Norkin, L.C. (2011). Taxonomical developments in the family Polyomaviridae. Archives of Virology, 12 May [Epub ahead of print], DOI 10.1007/s00705-011-1008-x, ISSN 0304-8608 
Kaae, J.; Hansen, A.V.; Biggar, R.J.; Boyd, H.A.; Moore, P.S.; Wohlfart, J. \& Melbye, M. (2010). Merkel cell carcinoma: incidence, mortality, and risk of other cancers. Journal of the National Institute of Cancer, Vol. 102, No. 11 (June 2010), pp. 793-801, ISSN 0027-8874

Kantola, K.; Sadeghi, M.; Lahtinen, A.; Koskenvuo, M.; Aaltonen, L.M.; Möttönen, M.; Rahiala, J.; Saarinen-Pihkala, U.; Riikonen, P.; Jartti, T.; Ruuskanen, O.; SöderlundVenermo, M. \& Hedman. K. (2009). Merkel cell polyomavirus DNA in tumor-free tonsillar tissues and upper respiratory tract samples: implications for respiratory transmission and latency. Journal of Clinical Virology, Vol. 45, No. 4 (August 2009), pp. 292-295, ISSN 1386-6532

Kassem, A.; Schöpflin, A.; Diaz, C.; Weyers, W.; Stickeler, E.; Werner, M. \& Zur Hausen, A. (2008).Frequent detection of Merkel cell polyomavirus in human Merkel cell carcinomas and identification of a unique deletion in the VP1 gene. Cancer Research. Vol. 68, No. 13 (July 2008), pp. 5009-5013, ISSN 0008-5472

Katano, H.; Ito, H.; Suzuki, Y.; Nakamura, T.; Sato, Y.; Tsuji, T.; Matsuo, K.; Nakagawa, H. \& Sata, T. (2009). Detection of Merkel cell polyomavirus in Merkel cell carcinoma and Kaposi's sarcoma. Journal of Medical Virology, Vol. 81, No. 11, pp. 1951-1958, ISSN 1096-9071

Kawai, S. \& Hanafusa, H. (1971). The effects of reciprocal changes in temperature on the transformed state of cells infected with a rous sarcoma virus mutant. Virology, Vol. 46, No. 2 (November 1971), pp. 470-479, ISSN 0042-6822

Kean, J.M.; Rao, S.; Wang, M. \& Garcea, R.L. (2009). Seroepidemiology of human polyomaviruses. PLoS Pathogens, Vol. 5, No. 3, pp. e1000363, ISSN 1553-7366

Kennedy, M.M.; Blessing, K.; King, G. \& Kerr, K.M. (1996). Expression of bcl-2 and p53 in Merkel cell carcinoma. An immunohistochemical study. American Journal of Dermatopathology, Vol. 18, No. 3 (June 1996) pp. 273-277, ISSN 0193-1091

Khalili K, White, M.K.; Sawa, H.; Nagashima, K. \& Safak, M. 2005. The agnoprotein of polyomaviruses: a multifunctional auxiliary protein. Journal of Cellular Physiology, Vol. 204, No. 1 (July 2005), pp. 1-7, ISSN 00219541

Kim, J. \& McNiff, J.M. (2008). Nuclear expression of surviving portends a poor prognosis in Merkel cell carcinoma. Modern Pathology, Vol. 21, No. 6 (June 2008), pp. 764-769, ISSN 0893-3952

Klein, A.; Guhl, E.; Zollinger, R.; Tzeng, Y.J.; Wessel, R.; Hummel, M.; Graesmann, M. \& Graesmann, A. (2005). Gene expression profiling: cell cycle deregulation and aneuploidy do not cause breast cancer formation in WAP-SVT/t transgenic animals. Journal of Molecular Medicine, Vol. 83, No. 5 (May 2005), pp. 362-376, ISSN 0946-2716

Knowles, W.A. (2006). Discovery and epidemiology of the human polyomaviruses BK virus (BKV) and JC virus (JCV). Advances in Experimental Medicine and Biology, Vol. 577, pp. 19-45, ISSN 0065-2598

Koljonen, V.; Kukko, H.; Pukkala, E.; Sankila, R.; Böhling, T.; Tukiainen, E.; Sihto, H. \& Joensuu, H. (2009). Chronic lymphocytic leukaemia patients have a high risk of Merkel-cell polyomavirus DNA-positive Merkel-cell carcinoma. British Journal of Cancer, Vol. 101, No.8 (September 2010), pp. 1444-1447, ISSN 0007-0920

Krasagakis, K.; Kruger-Krasagakis, S.; Tzanakakis, G.N.; Darivianaki, K.; Stathopoulus, E.N. \& Tosca, A.D. (2008). Interferon-alpha inhibits proliferation and induces apoptosis 
of Merkel cell carcinoma in vitro. Cancer Investigation, Vol. 26, No. 6 (July 2008), pp.562-568, ISSN 0735-7907

Kuwamoto, S.; Higaki, H.; Kanai, K.; Iwasaki, T.; Sano, H.; Nagata, K.; Kato, K.; Kato, M.; Murakami, I.; Horie, Y.; Yamamoto, O. \& Hayashi, K. (2011). Association of Merkel cell polyomavirus infection with morphologic differences in Merkel cell carcinoma. Human Pathology, Vol. 42, No. 5, (May 2011), pp. 632-640, ISSN 0046-8177

Kwun, H.J.; Guastafierro, A.; Shuda, M.; Meinke, G.; Bohm, A.; Moore, P.S. \& Chang, Y. (2009). The minimum replication origin of Merkel cell polyomavirus has a unique large T-antigen loading architecture and requires small t-antigen expression for optimal replication. Journal of Virology, Vol. 83, No. 23 (September 2009), pp. 1211812128 ISSN 0022-538X

Lacour, J.P.; Dubois, D.; Pisani, A. \& Ortonne, J.P. (1991). Anatomical mapping of Merkel cells in normal adult epidermis. British Journal of Dermatology, Vol. 156, No. 6 (December 1991), pp. 535-542, ISSN 1365-2133

Lassacher, A.; Heitzer, E.; Kerl, H. \& Wolf, P. (2008). p14ARF Hypermethylation is common but INK4a-ARF locus or p53 mutations are rare in Merkel cell carcinoma. Journal of Investigative Dermatology, Vol. 128, No. 7 (July 2008), pp. 1788-1796, ISSN 0022-202X

Laude, H.C.; Jonchère, B.; Maubec, E.; Carlotti, A.; Marinho, E.; Couturaud, B.; Peter, M.; Sastre-Garau, X.; Avril, M.F.; Dupin, N. \& Rozenberg, F. (2010). Distinct Merkel cell polyomavirus molecular features in tumour and non tumour specimens from patients with Merkel cell carcinoma. PLoS Pathogens, Vol. 6, No. 8 (Augustus 2010), pp. e10001076, ISSN 1553-7366

Lemos, B. \& Nghiem, P. (2007). Merkel cell carcinoma: more deaths but still no pathway to blame. Journal of Investigative Dermatology, Vol. 127, No. 9 (September 2007), pp. 2100-2103, ISSN 0022-202X

Leonard, J.H.; Dash, P.; Holland, P.; Kearsley, J.H. \& Bell J.R. (1995). Characterisation of four merkel cell carcinoma adherent cell lines. International Journal of Cancer, Vol. 60, No. 1 (January 1995), pp. 100-107, ISSN 1097-0215

Leonard, J.H.; Cook, A.L.; Nancarrow, D.; Hayward, N.; Van Gele, M.; Van Roy, N. \& Speleman, F. (2000). Cancer detection and Prevention, Vol. 24, No. 6 (December 2000), pp. 620-627, ISSN 0361-090X

Lewis, J.S.Jr.; Duncavage, E. \& Klonowski, P.W. (2010). Oral cavity neuroendocrine carcinoma: a comparison study with cutaneous Merkel cell carcinoma and other mucosal head and neck neuroendocrine carcinomas. Oral Surgery, Oral Medicine, Oral Pathology, Oral Radiology \& Endodontics, Vol. 110, No. 2, (August 2010), pp. 209217, ISSN 1079-2104

Lin, Z. \& Flemington, E.K. (2011). miRNAs in the pathogenesis of oncogenic human viruses. Cancer Letters, Vol. 305, No. 2 (June 2011), pp. 186-199, ISSN 0304-3835

Loyo, M.; Guerrero-Preston, R.; Brait, M.; Hoque, M.O.; Chuang, A.; Kim, M.S.; Sharma, R.; Liégeois, N.J.; Koch, W.M.; Califano, J.A.; Westra, W.H. \& Sidransky, D. (2010). Quantitative detection of Merkel cell virus in human tissues and possible mode of transmission. International Journal of Cancer, Vol. 126, No. 12 (June 2010), pp. 29912996, ISSN 1097-0215

Maginnis, M.S. \& Atwood, W.J. (2009). JC virus: an oncogenic virus in animals and humans? Seminars in Cancer Biology, Vol. 19, No. 4 (August 2004), pp. 261-269, ISSN 1044$579 \mathrm{X}$ 
Mahrle, G. \& Orfanos, C.E. (1974). Merkel cells as human cutaneous neuroreceptor cells : Their presence in dermal neural corpuscles and in the external hair root sheath of human adult skin. Archives für Dermatologische Forschung, Vol. 251, No.1 (March 1974), pp. 19-26, ISSN 0340-3696

Maricich, S.M.; Wellnitz, S.A.; Nelson, A.M.; Lesniak, D.R.; Gerling, G.J.; Lumpkin, E.A. \& Zoghbi, H.Y. (2009). Merkel cells are essential for light-touch responses. Science, Vol. 324, No. 5934 (June 2009), pp. 1580-1582, ISSN 0036-8075

Martin, J.D.; King, D.M.; Slauch, J.M. \& Frisque, R.J. (1985). Differences in regulatory sequences of naturally occurring JC virus variants. Journal of Virology, Vol. 53, No. 1 (January 1985), pp. 306-311, ISSN 0022-538X

Mateer, S.C.; Fedorov, S.A. \& Mumby, M.C. (1998). Identification of structural elements involved in the interaction of simian virus 40 small tumor antigen with protein phosphatase 2A. Journal of Biological Chemistry, Vol. 273, No. 52 (December 1998), pp. 35339-34635, ISSN 0021-9258

Matthews, M.R.; Wang, R.C.; Reddick, R.L.; Saldivar, V.A. \& Browning, J.C. (2011). Viralassociated trichodysplasia spinulosa: a case with electron microscopic and molecular detection of the trichodysplasia spinulosa-associated human polyomavirus. Journal of Cutaneous Pathology Vol. 38, No. 5 (May 2011), pp.420-431, ISSN 1600-0560

Matsuoka, M. \& Jeang, K.T. (2007). Human T-cell leukaemia virus type 1 (HTLV-1) infectivity and cellular transformation. Nature Reviews Cancer, Vol. 7, No. 4 (April 2007), pp. 270-280, ISSN 1474-175X

Mertz, K.D.; Pfaltz, M.; Junt, T.; Schmid, M.; Fernandez-Figueras, M.T.; Pfaltz, K.; Barghorn, A. \& Kempf. W. (2010a). Merkel cell polyomavirus is present in common warts and carcinoma in situ of the skin. Human Pathology, Vol. 41, No. 10 (October 2010), pp. 1369-1379.

Mertz, K.D.; Junt, T.; Schmid, M.; Pfaltz, M. \& Kempf W. (2010b). Inflammatory monocytes are a reservoir for Merkel cell polyomavirus. Journal of Investigative Dermatology, Vol. 130, No. 4 (April 2010), pp. 1146-1151, ISSN 0022-202X

Moens, U.; Johansen, T.; Johnsen, J.I.; Seternes, O.M. \& Traavik, T. (1995). Noncoding control region of naturally occurring BK virus variants: sequence comparison and functional analysis. Virus Genes, Vol. 10, No. 3, pp. 261-275, ISSN 0920-8569

Moens, U.; Seternes, O.M.; Johansen, B. \& Rekvig, O.P. (1997) Mechanisms of transcriptional regulation of cellular genes by SV40 large T- and small t-antigens. Virus Genes, Vol. 15, No. 2, pp. 135-154, ISSN 0920-8569

Moens, U.; Van Ghelue, M. \& Johannessen, M. (2007a). Oncogenic potentials of the human polyomavirus regulatory proteins. Cellular and Molecular Life Sciences, Vol. 64, No. 13 (July 2007), pp. 1656-1678, ISSN 1420-682X

Moens, U.; Van Ghelue, M. \& Johannessen, M. (2007b). Human polyomaviruses: Molecular mechanisms for transformation and their association with cancers, In: New Research on Oncogenic Viruses, Tunely EI, pp. 1-63, Nova Science Publishers, ISBN: 978-1-60021-585-8, New York

Moens, U.; Johannessen, M.; Bárcena-Panero, A.; Gerits, N. \& Van Ghelue, M. (2010). Emerging polyomaviruses in the human population. Reviews in Infection, Vol. 1, No. 2, (May 2010), pp. 59-93, ISSN 1837-6746 
Moens, U.; Ludvigsen, M.; \& Van Ghelue, M. (2011). Human polyomaviruses in skin diseases. Pathology Research International, in press.

Mogha, A.; Fautrel, A.; Mouchet, N.; Guo, N.; Corre, N.; Adamski, H.; Watier, E.; Misery, L. \& Galibert, M.D. (2010). Merkel cell polyomavirus small T antigen mRNA level is increased following in vivo UV-radiation. PLoS One, Vol.5, No. 7 (July 2010), pp. e11423, ISSN.

Moll, I.; Roessler, M.; Brandner, J.M.; Eispert A.C.; Houdek, P. \& Moll, R. (2005). Human Merkel cells--aspects of cell biology, distribution and functions. European Journal of Cell Biology, Vol. 84, No. 2-3 (March 2005), pp. 259-271, ISSN 0171-9335

Nakajima, H.; Takaishi, M.; Yamamoto, M.; Kamijima, R.; Kodama, H.; Tarutani, M. \& Sano, S. (2009). Screening of the specific polyomavirus as diagnostic and prognostic tools for Merkel cell carcinoma. Journal of Dermatological Science, Vol. 56, No. 3 (December 2009), pp. 210-212, ISSN 0923-1811

Nakamura, T.; Sato, Y.; Watanabe, D.; Ito, H.; Shimonohara, N.; Tsuji, T.; Nakajima, N.; Suzuki, Y.; Matsuo, K.; Nakagawa, H.; Sata, T. \& Katano, H. (2010). Nuclear localization of Merkel cell polyomavirus large $\mathrm{T}$ antigen in Merkel cell carcinoma. Virology, Vol. 398, No. 2, pp. 273-279, ISSN 0042-6822

Padgett, B.L.; Walker, D.L.; Zu Rhein, G.M.; Eckroade, R.J. \& Dessel, B.H. (1971). Cultivation of papova-like virus from human brain with progressive multifocal leukoencephalopathy. Lancet Vol.1, No. 7712, (June 1971), pp.1257-1260, ISSN 01406736

Paik, J.Y.; Hall, G.; Clarkson, A.; Lee, L.; Toon, C.; Colebatch, A.; Chou, A. \& Gill, A.J. (2011). Immunohistochemistry for Merkel cell polyomavirus is highly specific but not sensitive for the diagnosis of Merkel cell carcinoma in the Australian population. Human Pathology. (March 2011). [Epub ahead of print] ISSN 1532-8392

Pancaldi, C.; Corazzari, V.; Maniero, S.; Mazzoni, E.; Martini, F. \& Tognon, M. (2011). Merkel cell polyomavirus DNA sequenze in the buffy coats of healthy blood donors. Blood. Vol. 117, No. 26 (June 2011), pp. 7099-7101, ISSN 0006-4971

Paolini, F.; Donati. P.; Amantea, A.; Bucher, S.; Migliano, E. \& Venuti, A. (2011). Merkel cell polyomavirus in Merkel cell carcinoma of Italian patients. Virology Journal, Vol. 8, (March 2011), pp. 103-105, ISSN 1743-422X

Pastrana, D.V.; Tolstov Y.L.; Becker, J.C.; Moore, P.S.; Chang, Y. \& Buck, C.B. (2009). Quantitation of human seroresponsiveness to Merkel cell polyomavirus. PLoS Pathogens, Vol. 5, No. 9 (September 2009), pp. e1000578, ISSN 1553-7366

Paulson, K.G.; Lemos, B.D.; Feng, B.; Jaimes, N.; Penas, P.F.; Bi, X.; Maher, E.; Cohen, L.; Leonard, J.H.; Granter, S.R.; Chin, L. \& Nghiem, P. (2009). Array-CGH reveals recurrent genomic changes in Merkel cell carcinoma including amplification of LMyc. Journal of Investigative Dermatology, Vol. 129, No. 6 (June 2009), pp. 1547-1555, ISSN 0022-202X

Paulson, K.G.; Carter, J.J.; Johnson, L.G.; Cahill, K.W.; Iyer, J.G.; Schrama, D.; Becker, J.C.; Madeleine, M.M.; Nghiem, P. \& Galloway, D.A. (2010). Antibodies to Merkel cell polyomavirus $\mathrm{T}$ antigen oncoproteins reflect tumor burden in Merkel cell carcinoma carcinoma patients. Cancer Research, Vol. 70, No. 21 (November 2010), pp. 8388-8397, ISSN 1538-7445

Paulson, K.G.; Iyer, J.G.; Tegeder, A.R.; Thibodeau, R.; Schelter, J.; Koba, S.; Schrama, D.; Simonson, W.T.; Lemos, B.D.; Byrd, D.R.; Koelle, D.M.; Galloway, D.A.; Leonard, 
J.H.; Madeleine, M.M.; Argenyi, Z.B.; Disis, M.L.; Becker, J.C.; Cleary, M.A. \& Nghiem, P. (2011). Transcriptome-Wide studies of Merkel cell carcinoma and calidation of intratumoral CD8+ lymphocyte invasion as an independent predictor of survival. Journal of Clinical Oncology, Vol. 29, No. 12, (April 2011), pp. 1539-1546, ISSN 1527-7755

Pectasides, D.; Pectasides, M. \& Economopoulos, T. (2006). Merkel cell cancer of the skin. Annals of Oncology, Vol. 17, No. 10 (October 2006), pp. 1489-1495, ISSN 0923-7534

Pulitzer, M.P.; Amin, B.D. \& Busam, K.J. (2009). Merkel cell carcinoma. Advances in Anatomic Pathology, Vol. 16, No. 3 (June 2009), pp. 135-144, ISSN 1072-4109

Ramahi, E.; Choi, J.; Fuller, C.D. \& Eng, T.Y. (2011). Merkel cell carcinoma. American Journal of Clinical Oncology, March 17 [Epub ahead of print].ISSN 0277-3732

Rathi, A.V.; Sáenz Robles, M.T.; Cantalupo, P.G.; Whitehead, R.H. \& Pipas, J.M. (2009). Simina virus $\mathrm{T}$-antigen-mediated gene regulation in enterocytes is controlled primarily by the Rb-E2F pathway. Journal of Virology, Vol. 83, No. 18 (September 2009), pp. 9521-9531, ISSN 0022 538X

Ricciardiello, L.; Chang, D.K.; Laghi, L.; Goel, A.; Chang, C.L. \& Boland, C.R. (2001). Mad-1 is the exclusive JC strain present in the human colon, and its transcriptional control region has a deleted 98-base-pair sequence in colon cancer tissues. Journal of Virology, Vol. 75, No. 4 (February 2001), pp. 1996-2001, ISSN 0022-538X

Ridd, K.; Yu, S. \& Bastian, B.C. (2009). The presence of polyomavirus in non-melanoma skin cancer in organ transplant recipients is rare. Journal of Investigative Dermatology, Vol. 129, No. 1, (January 2009), pp.250-252, ISSN 0022-202X

Sariyer, I.K.; Akan, I.; Palermo, V.; Gordon, J.; Khalili, K. \& Safak, M. (2006), Phosphorylation mutants of JC virus agnoprotein are unable to sustain the viral infection cycle. Journal of Virology, Vol. 80, No. 8 (April 2006), pp. 3893-3903, ISSN 0022-538X

Sastre-Garau, X.; Peter, M.; Avril, M.F.; Laude, H.; Couturier, J.; Rozenberg, F.; Almeida, A.; Boitier, F.; Carlotti, A.; Couturaud, B. \& Dupin, N. (2009). Merkel cell carcinoma of the skin: pathological and molecular evidence for a causative role of $\mathrm{MCV}$ in oncogenesis. Journal of Pathology, Vol. 218, No. 1 (May 2009), pp. 48-56, ISSN 10969896

Schowalter, R.M.; Pastrana, D.V.; Pumphrey, K.A.; Moyer, A.L. \& Buck, C.B. (2010). Merkel cell polyomavirus and two previously unknown polyomaviruses are chronically shed from human skin. Cell Host $\mathcal{E}$ Microbe, Vol.7, No. 6 (June 2010), pp. 509-515, ISSN 1931-3128

Schmitt, M.; Hofler, D.; Koleganova, N. \& Pawlita, M. (2011). Human polyomaviruses and other human viruses in neuroendocrine tumors. Cancer Epidemiology Biomarkers $\mathcal{E}$ Prevention, Vol. 20, No.7 (July 2011), pp. 1558-1561

Schrama, D.; Thiemann, A.; Houben, R. Kähler, K.C.; Becker, J.C. \& Hauschild A. (2010). Distinction of 2 different primary Merkel cell carcinomas in 1 patient by Merkel cell polyomavirus genome analysis. Archives of Dermatology. Vol. 146, No. 6 (June 2010), pp. 687-689, ISSN 0003-987X

Scuda, N.; Hofmann, J.; Calvignac-Spencer, S.; Ruprecht, K.; Liman, P.; Kühn, J.; Hengel, H. \& Ehlers, B. 2011. A novel human polyomavirus closely related to the African green monkey-derived lymphotropic polyomavirus (LPV). Journal of Virology, Vol. 85, No. 9 (May 2011), ISSN 0022-538X 
Seo, G.J.; Fink, L.H.L.; O’Hara, B.; Atwood, W.J. \& Sullivan, C.S. (2008). Evolutionarily conserved function of a viral microRNA. Journal of Virology, Vol 82, No. 20 (October 2008), pp. 9823-9828, ISSN 0022-538X

Seo, G.J.; Chen, C.J. \& Sullivan, C.S. (2009). Merkel cell polyomavirus encodes a microRNA with the ability to autoregulate viral gene expression," Virology, Vol. 382, No. 2 (January 2009), pp. 183-187, ISSN 0042-6822

Sharp, C.P.; Norja, P.; Anthony, I.; Bell, J.E. \& Simmonds, P. (2009). Reactivation and mutation of newly discovered WU, KI, and Merkel cell carcinoma polyomaviruses in immunosuppressed individuals. Journal of Infectious Diseases, Vol. 199, No. 2 (July 2009), pp. 398-404, ISSN 0022-1899

Shuda, M.; Arora, R.; Kwun, H.J.; Feng, H.; Sarid, R.; Fernandez-Figueras, M.T.; Tolstov, Y.; Gjoerup, O.; Mansukhani, M.M.; Swerdlow, S.H.; Chaudhary, P.M.; Kirkwood, J.M.; Nalesnik, M.A.; Kant, J.A.; Weiss, L.M.; Moore, P.S. \& Chang, Y. (2009). Human Merkel cell polyomavirus infection I. MCV T antigen expression in Merkel cell carcinoma, lymphoid tissues and lymphoid tumors. International Journal of Cancer, Vol.125, No. 6 (September 2009), pp, 1243-1249, ISSN 1097-0215

Sihto, H.; Kukko, H.; Koljonen, V.; Sankila, R.; Böhling, T. \& Joensuu H. (2009). Clinical factors associated with Merkel cell polyomavirus infection in Merkel cell carcinoma. Journal of the National Cancer Institute, Vol. 101, No. 13 (July 2009), pp. 938-945, ISSN 0027-8874

Sihto, H.; Kukko, H.; Koljonen, V.; Sankila, R.; Böhling, T. \& Joensuu H. (2011). Merkel cell polyomavirus infection, large $\mathrm{T}$ antigen, retinoblastoma protein and outcome in Merkel cell carcinoma. Clinical Cancer Research, Vol. 17, No. 14 (July 2011), pp. 48064813, ISSN 1078-0432

Simmons, D.T.; Gai, D.; Parsons, R.; Debes, A. \& Roy, R. (2004). Assembly of the replication initiation complex on SV origin DNA. Nucleic Acids Research, Vol. 32, No. 3 (February 2004), pp. 1103-1112, ISSN 0305-1048

Skalsky, R.L. \& Cullen, B.R. (2010). Viruses, microRNAs, and host interactions. Annual Reviews of Microbiology, Vol. 64, pp. 123-141, ISSN 0066-4227

Southgate, J.; Harnden, P. \& Trejdosiewicz, L.K. (1999). Cytokeratin expression patterns in normal and malignant urothelium: a review of the biological and diagnostic implications. Histology and Histopathology, Vol. 14 No. 2 (April 1999), pp. 657-664, ISSN 0213-3911

Stoner, G.L. \& Hübner, R. (2001). The human polyomaviruses: past, present, and future, In: Human polyomaviruses. Molecular and clinical perspectives, Khalili, K.; \& Stoner, G.L. pp. 611-663, Wiley-Liss, ISBN 0-471-39009-7, New York.

Sullivan, C.S.; Grundhoff, A.T.; Tevethia, S.; Pipas, J.M. \& Ganem, D. (2005). SV40-encoded microRNAs regulate vral gene expression and reduce susceptibility to cytotoxic $\mathrm{T}$ cells. Nature, Vol. 435, No. 7042 (June 2005), pp. 682-686 ISSN 0028-0836

Suzuki, T.; Orba, Y.; Okada, Y.; Sunden, Y.; Kimura, T.; Tanaka, S.; Nagashima, K.; Hall, W.W. \& Sawa, H. (2010). The human polyoma JC virus agnoprotein acts as a viroporin. PLoS Pathogens, Vol. 6, No. 3 (March 2010), pp. e1000801, ISSN 1553-7366

Szeder, V.; Grim, M.; Halata, Z. \& Sieber-Blum, M. (2003). Neural crest origin of mammalian Merkel cells. Developmental Biology, Vol. 253, No. 2 (January 2003), pp. 258-263, ISSN 0012-1606 
Tai, P. (2008). Merkel cell cancer: update on biology and treatment. Current Opinion in Oncology, Vol. 20, No. 2 (March 2008), pp. 196-200, ISSN 1040-8746

The Rockville Merkel cell carcinoma group (2009). Merkel cell carcinoma: recent progress and current priorities on etiology, pathogenesis, and clinical management. Journal of Clinical Oncology, Vol. 27, No. 24 (August 2009), pp. 4021-4026, ISSN 0732-183X

Toker, C. (1972). Trabecular carcinoma of the skin. Archives of Dermatology, Vol. 105, No.1 (January 1972), pp. 107-110, ISSN 0003987X

Tolstov, Y.L.; Pastrana, D.V.; Feng, H.; Becker, J.C.; Jenkins, F.J.; Moschos, S.; Chang, Y.; Buck, C.B. \& Moore, P.S. (2009). Human Merkel cell polyomavirus infection II. $\mathrm{MCV}$ is a common human infection that can be detected by conformational capsid epitope immunoassays. International Journal of Cancer, Vol. 125, No. 6 (September 2009) , pp. 1250-1256, ISSN 1097-0215

Toracchio, S.; Foyle, A.; Sroller, V.; Reed, J.A.; Wu, J.; Kozinetz, C.A. \& Butel, J.S. (2010). Lymphotropism of Merkel cell polyomavirus infection, Nova Scotia, Canada. Emerging Infectious Diseases, Vol. 16, No. 11 (November 2010), pp. 1702-1709, ISSN 1080-0059.

Touzé, A.; Gaitan, J.; Maruani, A.; Le Bidre, E.; Doussinaud, A.; Clavel, C.; Durlach, A.; Aubin, F.; Guyétant, S.; Lorette, G. \& Coursaget, P. (2009). Merkel cell polyomavirus strains in patients with merkel cell carcinoma. Emerging Infectious Diseases, Vol. 15, No. 6, (June 2009), pp. 960-962, ISSN 1080-6059

Touzé, A.; Le Bidre, E.; Laude, H.; Fleury, M.J.; Cazal, R.; Arnold, F.; Carlotti, A.; Maubec, E.; Aubin, F.; Avril, M.F.; Rozenberg, F.; Tognon, M.; Maruani, A.; Guyetant, S.; Lorette, G. \& Coursaget P. (2011). High Levels of Antibodies Against Merkel Cell Polyomavirus Identify a Subset of Patients With Merkel Cell Carcinoma With Better Clinical Outcome. Journal of Clinical Oncology, Vol. 29, No. 12 (April 2011), pp. 1612-1619, ISSN 0732-183X

Tsai, W.L. \& Chung, R.T. (2010). Viral hepatocarcinogenesis. Oncogene, Vol. 29, No. 16 (April 2010), pp. 2309-2324, ISSN 0950-9232

van der Meijden, E.; Janssens, R.W.A.; Lauber, C.; Bavinck, J.N.; Gorbalenya, A.E. \& Feltkamp, M.C.W. (2010). Discovery of a new human polyomavirus associated with trichodysplasia spinulosa in an immunocompromized patient. PLoS Pathogens, Vol. 6, No. 7 (July 2010), pp. e1001024, ISSN 1553-7366

Van Gele, M.; Leonard, J.H.; Van Roy, N.; Cook, A.L.; De Paepe, A. \& Speleman, F. (2001). Frequent allelic loss at 10q23 but low incidence of PTEN mutations in Merkel cell carcinoma. International Journal of Cancer, Vol. 92, No. 3 (May 2001), pp. 409-413, ISSN 1097-0215

Van Gele, M.; Boyle, G.M.; Cook, A.L.; Vandesompele, J.; Boonefaes, T.; Rottiers, P.; Van Roy N, De Paepe, A.; Parsons, P.G.; Leonard, J.H. \& Speleman, F. (2004). Geneexpression profiling reveals distinct expression patterns of Classic versus variant Merkel cell phenotype and new classifier genes to distinguish Merkel cell from small-cell lung carcinoma. Oncogene, Vol. 23, No.15 (April 2004), pp. 2732-2742, ISSN 0950-9232

Van Keymeulen A, Mascre G, Youseff, K.K.; Harel, I.; Michaux, C.; de Geest, N.; Szpalski, C.; Achouri, Y.; Bloch, W.; Hassan, B.A. \& Blanpain, C. (2009). Epidermal progenitors give rise to Merkel cells during embryonic development and adult homeostasis. Journal of Cell Biology, Vol. 187, No. 1 (October 2009), pp. 91-100, ISSN 1540-8140 
Varga, E.; Kiss, M.; Szabó, K. \& Kemény, L. (2009) Detection of Merkel cell polyomavirus DNA in Merkel cell carcinomas. British Journal of Dermatology, Vol. 16, No. 4 (October 2009), pp. 930-932, ISSN 1365-2133

Vilchez, R.A. \& Butel, J.S. (2004). Emergent human pathogen simian virus 40 and its role in cancer. Clinical Microbiology Reviews Vol. 17, No. 3 (July 2004), pp. 495-508, ISSN 0893-8512

Vogelstein, B.; Lane, D. \& Levine, A.J. (2000). Surfing the p53 network. Nature, Vol. 408, No. 6810 (November 2000), pp. 307-310, ISSN 0028-0836

Vousden, K. H. \& Prives, C. (2009). Blinded by the light: the growing complexity of p53. Cell, Vol. 137, No. 3 (January 2009), pp. 413-431 ISSN 0092-8674

Waltari, M.; Sihto, H.; Kukko, H.; Koljonen, V.; Sankila, R.; Böhling, T. \& Joensuu, H. Association of Merkel cell polyomavirus infection with tumor p53, KIT, stem cell factor, PDGFR-alpha and survival in Merkel cell carcinoma. International Journal of Cancer, 2010 Oct 14. DOI: 10.1002/ijc.25720 ISSN (electronic): 1097-0215 PMID: 20949558

Wang, Q.; Li, D.C.; Li, Z.F.; Liu, C.X.; Xiao, Y.M.; Zhang, B.; Li, X.D.; Zhao, J.; Chen, L.P.; Xing, X.M.; Tang, S.F.; Lin, Y.C.; Lai, Y.D.; Yang, P.; Zeng, J.L.; Xiao, Q.; Zeng, X.W.; Lin, Z.N.; Zhuang, S.M. \& Chen, W. (2011). Upregulation of miR-27a contributes to the malignant transformation of human bronchial epithelial cells induced by SV40 small T antigen. Oncogene, Apr 4 [Epub ahead of print].

Werling, A.M.; Doerflinger, Y.; Brandner, J.M.; Fuchs, F.; Becker, J.C.; Schrama, D.; Kurzen, H.; Goerdt, S. \& Peitsch, W.K. (2011). Homo- and heterotypic cell-cell contacts in Merkel cells and Merkel cell carcinomas: heterogeneity and indications for cadherin switching. Histopathology, Vol. 58, No. 2, (January 2011), pp. 286-303, ISSN: 13652559

Wetzels, C.T.; Hoefnagel, J.G.; Bakkers, J.M.; Dijkman, H.B.; Blokx, W.A. \& Melchers, W.J. (2009). Ultrastructural proof of polyomavirus in Merkel cell carcinoma tumour cells and its absence in small cell carcinoma of the lung. PLoS One. Vol. 4, No 3 (March 2009) e4958, ISSN 1932-6203

Wieland, U.; Mauch, C.; Kreuter, A.; Krieg, T. \& Pfister, H. (2009). Merkel cell polyomavirus DNA in persons without Merkel cell carcinoma. Emerging Infectious Diseases, Vol. 15, No. 9 (September 2009), pp. 1496-1498, ISSN 1080-6059

Wieland, U.; Silling, S.; Scola, N.; Potthoff, A.; Gambichler, T.; Brockmeyer, N.H.; Pfister, H. \& Kreuter, A. (2011). Merkel cell polyomavirus infection in HIV-positive men. Archives of Dermatology, Vol. 147, No. 4 (April 2011), pp. 401-406, ISSN 0003987X

Wong, H.H.; \& Wang, J. (2010). Merkel cell carcinoma. Archives of Pathology \& Laboratory Medicine, Vol. 134, No. 11 (November 2010), pp. 1711-1716, ISSN 0003-9985

Woo, K.J.; Choi, Y.L.; Jung, H.S.; Jung, G.; Shin, Y.K.; Jang, K.T.; Han, J. \& Pyon, J.K. (2010). Merkel cell carcinoma: our experience with seven patients in Korea and a literature review. Journal of Plastic, Reconstructive \& Aesthetic Surgery, Vol. 63, No. 12 (December 2010), pp. 2064-2070, ISSN 1748-6815

Wu, K.N.; McCue, P.A.; Berger, A.; Spiegel, J.R.; Wang, Z.X. \& Witkiewicz, A.K. (2010). Detection of Merkel cell carcinoma polyomavirus in mucosal Merkel cell carcinoma. International Journal of Surgical Pathology, Vol. 18, No. 5 (October 2010), pp. 342-346, ISSN 1066-8969 
Yoshiike, K. \& Takemoto, K.K. (1986) Studies with BK virus and monkey lymphotropic papovavirus. In: The Papovaviridae: The polyomaviruses. Salzman, N.P. pp. 295-326, Plenum Press, ISBN 0-306-42308-1, New York and London.

zur Hausen, H. (2008a). Novel human polyomaviruses - re-emergence of a well known virus family as possible human carcinogens. International Journal of Cancer, Vol. 123, No. 2 (July 2008), pp. 247-250, ISSN 1097-0215

zur Hausen, H. (2008b). A specific signature of Merkel cell polyomavirus persistence in human cancer cells. Proceedings of the National Academy of Sciences of the United States of America, Vol. 105, No. 42 (October 2008), pp. 16063-16064, ISSN 0027-8424

zur Hausen, H. (2009). Papillomaviruses in the causation of human cancers - a brief historical account. Virology, Vol. 384, No. 2 (February 2009), pp. 260-265, ISSN 00426822 


\section{SKIN CANCERS}

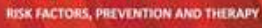

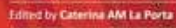

\section{Skin Cancers - Risk Factors, Prevention and Therapy \\ Edited by Prof. Caterina La Porta}

ISBN 978-953-307-722-2

Hard cover, 272 pages

Publisher InTech

Published online 14, November, 2011

Published in print edition November, 2011

Skin cancers are the fastest growing type of cancer in the United States and represent the most commonly diagnosed malignancy, surpassing lung, breast, colorectal and prostate cancer. In Europe, the British Isles have been the highest rates of skin cancer in children and adolescents. The overall idea of this book is to provide the reader with up to date information on the possible tools to use for prevention, diagnosis and treatment of skin cancer. Three main issues are discussed: risk factors, new diagnostic tools for prevention and strategies for prevention and treatment of skin cancer using natural compounds or nano-particle drug delivery and photodynamic therapy.

\section{How to reference}

In order to correctly reference this scholarly work, feel free to copy and paste the following:

Marijke Van Ghelue and Ugo Moens (2011). Merkel Cell Polyomavirus: A Causal Factor in Merkel Cell Carcinoma, Skin Cancers - Risk Factors, Prevention and Therapy, Prof. Caterina La Porta (Ed.), ISBN: 978953-307-722-2, InTech, Available from: http://www.intechopen.com/books/skin-cancers-risk-factorsprevention-and-therapy/merkel-cell-polyomavirus-a-causal-factor-in-merkel-cell-carcinoma

\section{INTECH}

open science | open minds

\section{InTech Europe}

University Campus STeP Ri Slavka Krautzeka 83/A 51000 Rijeka, Croatia Phone: +385 (51) 770447 Fax: +385 (51) 686166 www.intechopen.com

\section{InTech China}

Unit 405, Office Block, Hotel Equatorial Shanghai No.65, Yan An Road (West), Shanghai, 200040, China 中国上海市延安西路65号上海国际贵都大饭店办公楼 405 单元 Phone: +86-21-62489820

Fax: $+86-21-62489821$ 
(C) 2011 The Author(s). Licensee IntechOpen. This is an open access article distributed under the terms of the Creative Commons Attribution 3.0 License, which permits unrestricted use, distribution, and reproduction in any medium, provided the original work is properly cited. 